\title{
Fungal diseases: could nanostructured drug delivery systems be a novel paradigm for therapy?
}

This article was published in the following Dove Press journal:

International Journal of Nanomedicine

8 August 2016

Number of times this article has been viewed

\author{
Aline Raquel Voltan' \\ Guillermo Quindós 2 \\ Kaila P Medina Alarcón ${ }^{3}$ \\ Ana Marisa Fusco-Almeida ${ }^{3}$ \\ Maria José Soares Mendes- \\ Giannini ${ }^{3}$ \\ Marlus Chorilli' \\ 'Department of Drugs and Medicines, \\ Faculty of Pharmaceutical Sciences, \\ Univ. Estadual Paulista, Araraquara, \\ Sao Paulo, Brazil; ${ }^{2}$ Immunology, \\ Microbiology, and Parasitology \\ Department, Facultad de Medicina \\ y Odontología, Universidad del País \\ Vasco, Bilbao, Spain; ${ }^{3}$ Department \\ of Clinical Analysis, Faculdade de \\ Ciências Farmacêuticas, Univ. Estadual \\ Paulista, Araraquara, Sao Paulo, Brazil
}

\begin{abstract}
Invasive mycoses are a major problem for immunocompromised individuals and patients in intensive care units. Morbidity and mortality rates of these infections are high because of late diagnosis and delayed treatment. Moreover, the number of available antifungal agents is low, and there are problems with toxicity and resistance. Alternatives for treating invasive fungal infections are necessary. Nanostructured systems could be excellent carriers for antifungal drugs, reducing toxicity and targeting their action. The use of nanostructured systems for antifungal therapy began in the 1990s, with the appearance of lipid formulations of amphotericin B. This review encompasses different antifungal drug delivery systems, such as liposomes, carriers based on solid lipids and nanostructure lipids, polymeric nanoparticles, dendrimers, and others. All these delivery systems have advantages and disadvantages. Main advantages are the improvement in the antifungal properties, such as bioavailability, reduction in toxicity, and target tissue, which facilitates innovative therapeutic techniques. Conversely, a major disadvantage is the high cost of production. In the near future, the use of nanosystems for drug delivery strategies can be used for delivering peptides, including mucoadhesive systems for the treatment of oral and vaginal candidiasis.
\end{abstract}

Keywords: fungal diseases, antifungal agents, amphotericin B, azoles, nanoparticles, nanotechnology

\section{Fungal diseases}

Fungal infections are a growing public health problem, mainly related to the advances of modern medicine in prolonging the lifespan and the quality of life of patients under severe clinical conditions. ${ }^{1}$ A range of new broad-spectrum antibiotics made it possible to successfully treat infections of many microorganisms, which had previously been fatal. This resulted in prolonged survival of patients highly susceptible to infection. Thus, fungal infections emerge as leading causes of morbidity and mortality in immunocompromised and intensive care unit patients. ${ }^{2}$

In recent decades, bacteria and fungi have developed considerable resistance to many traditional and modern synthetic drugs. ${ }^{3}$ In this context, nanoparticles (NPs) can also overcome the drug resistance mechanisms, related to decreased absorption, increased drug efflux from microbial cells, biofilm formation, or intracellularity. ${ }^{4}$ Finally, NPs deliver the highest dose of antimicrobial agents specifically to the site of infection, thus overcoming drug resistance with less adverse effects on the patient. ${ }^{5}$

\section{Pathogenic fungi}

Mycoses are among the most difficult global diseases to be controlled. Some conditions can be a predisposition to invasive mycoses, such as immunosuppression, neoplasia, and some chronic diseases. Oral candidiasis and vaginal candidiasis are the most
Correspondence: Marlus Chorilli;

Ana Marisa Fusco-Almeida

Medicamentos, Faculdade de Ciências

Farmacêuticas, Univ. Estadual Paulista,

Araraquara, São Paulo, Brazil

Tel +55 I6 330। 6998

Fax +55 I6 330I 6960

Email chorilli@fcfar.unesp.br;

ana.marisa@uol.com.br 
common fungal diseases. ${ }^{6}$ These superficial mycoses affect $25 \%-30 \%$ of human population. ${ }^{4}$ Candida albicans is also involved in denture stomatitis pathogenesis, a disease very common in older individuals. Other fungal diseases can be less frequent, but much more severe, such as asthma with fungal sensitization, allergic bronchopulmonary aspergillosis, invasive aspergillosis, chronic pulmonary aspergillosis, pneumocystosis, meningeal cryptococcosis, mucormycoses, or invasive candidiasis. ${ }^{7}$ Invasive fungal infections (IFIs) are less predominant, but their morbidity and mortality rates are high, killing about 1.5 million people per year. ${ }^{8}$ A total of ten genera of fungi have a high prevalence in infections, including Aspergillus, Candida, Cryptococcus, Blastomyces, Coccidioides, Histoplasma, Paracoccidioides, Penicillium, Pneumocystis, and Rhizopus. However, $90 \%$ of deaths are caused by Candida, Cryptococcus, Aspergillus and Pneumocystis. ${ }^{8}$ Bitar et $\mathrm{al}^{9}$ observed a higher incidence of candidemia (43.4\%), followed by Pneumocystis jirovecii pneumonia (26.1\%), invasive aspergillosis (23.9\%), cryptococcosis (5.2\%), and mucormycosis $(1.5 \%)$ in IFIs through a retrospective study conducted in France in 2001-2010. Among fungal infections, candidiasis is the most common fungal infection worldwide ${ }^{10}$ and an important cause of morbidity and mortality in bloodstream and other invasive infections among hospitalized patients in many countries of the world. ${ }^{11}$ C. albicans is the main etiology of candidiasis, but other species, such as Candida glabrata, Candida parapsilosis, or Candida krusei, are emerging as causes of nosocomial infections. ${ }^{12-14}$

Cryptococcus neoformans is the third most common cause of infectious complications in the central nervous system in AIDS patients: $:^{15} 1$ million new cases of cryptococcal meningitis occur each year causing $\sim 600,000$ deaths. ${ }^{16}$ Aspergillus fumigatus is the most common cause of invasive mycoses by filamentous fungi, with mortality rates of $40 \%-90 \%{ }^{17,18}$

\section{Antifungal drugs}

Antifungal resistance is an increasing threat for the effective treatment of invasive mycoses, making their therapy difficult, expensive, or even impossible. ${ }^{10}$ The current treatment approaches for IFIs are fairly limited and include three main classes of drugs: polyenes (amphotericin B [AmB]), azoles (fluconazole, isavuconazole, itraconazole, posaconazole, and voriconazole), and echinocandins (anidulafungin, caspofungin, and mycafungin). ${ }^{18}$ To obtain good clinical results in the treatment, early and appropriate treatment is required, but the activity of current antifungal agents is not predictably against emerging yeasts and filamentous fungi and can cause undesirable side effects. ${ }^{19}$ Older antifungal agents, such as AmB, despite their toxicity, are very important in the treatment of IFIs as they have a broad-spectrum and low resistance rates. ${ }^{20}$

Recent advances in antifungal chemotherapy with broadspectrum triazoles and echinocandins provide more effective and less toxic alternatives to conventional polyenes. Despite this, IFI mortality rates remain high, and there is a growing need for new therapeutic options. ${ }^{21}$ However, the rate of discovery of antifungal drugs is unlikely to be sufficient for the future demands, since few drugs are currently being discovered. In the early 1990s, two new antifungal drugs were approved by the US Food and Drug Administration (FDA), namely, fluconazole and itraconazole. ${ }^{22}$ Still in the 1990s, lipid formulations of AmB, amphotericin B lipid complex (ABLC, in 1995), amphotericin B colloidal dispersion (ABCD, in 1996), and liposomal AmB (L-AmB, in 1997) were all approved. In the 2000s, caspofungin (in 2001) and voriconazole (in 2002) ${ }^{23}$ were also approved. Micafungin was the second echinocandin antifungal agent approved by the FDA in 2005 and anidulafungin was the third to be approved in 2006. ${ }^{24}$ Posaconazole was approved in 2006 as oral suspension, and in 2013 and 2014 for use in tablets and intravenously, respectively. ${ }^{22}$ More recently, in March 2015, the FDA approved isavuconazole ${ }^{25}$ (Figure 1).

Given the current panorama of microbial resistance and lack of new drugs, NPs appear to aid in the treatment of various diseases, including mycoses. ${ }^{26} \mathrm{NPs}$ can be defined as ultradispersed supramolecular structures with submicrometer

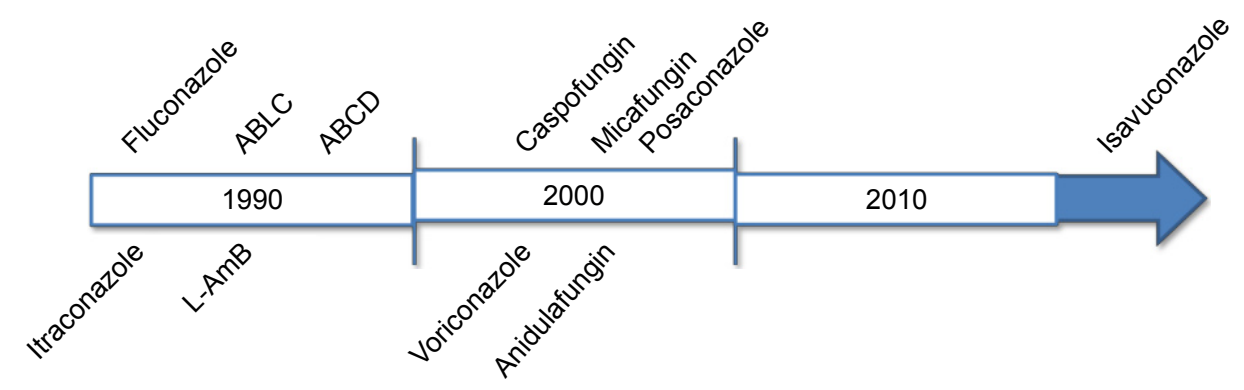

Figure I Time course of discovery of antifungal drugs.

Abbreviations: ABLC, amphotericin B lipid complex; ABCD, amphotericin B colloidal dispersion; L-AmB, liposomal amphotericin B. 
size ranging from $10 \mu \mathrm{m}$ to $1,000 \mu \mathrm{m}$. The drug may be dissolved, entrapped, encapsulated, or bound to a matrix of NPs, which acts as a reservoir for particulate systems and therefore plays an important role as a drug delivery system for clinical applications, particularly in oncology. ${ }^{27}$ Many studies have currently demonstrated the efficacy of antifungal agents incorporated into NPs for combating fungal infections. ${ }^{6-8}$ The production of NPs through nanotechnology has revolutionized the delivery of drugs. Today, there is a consensus that nanotechnology represents a miniaturization of objects, as well as the preparation of nanomaterials with physical and chemical properties that drastically differ from those of bulk materials because they are on a nanoscale. Until the early 1970s, the administration of pharmaceutical suspensions intravenously was considered impossible due to the risk of embolism. The current development of suspensions of NPs containing drugs (eg, nanomedicines or nanopharmaceuticals) is the use of NPs for treating, diagnosing, and preventing diseases. Through these, it is possible to increase the therapeutic index of various drugs by improving activity, reducing toxicity, and targeting them selectively toward diseased tissues and cells.

A noteworthy problem in the treatment of many diseases, including invasive mycoses, is the delivery of the drug to the target site, since the conventional drugs have limitations such as restricted efficacy, poor biodistribution, and lack of selectivity. The solution to this problem is the use of a drug delivery control system that can overcome these limitations and drawbacks. The therapy based on a delivery system is important to solve problems, regarding the balance between high drug concentrations and toxic effects. A major technological breakthrough in medicine has been the reduction in the particle size from micrometers to nanometers. ${ }^{28}$ Through small dimensions, NPs can target specific sites within the body as cells and tissues are permeable to them. Therefore, NPs can deliver the active drug to sites where conventional drugs do not reach, thus minimizing unwanted side effects. The therapeutic potential of NPs as carriers of drugs depends on their hydrodynamic size, shape, quantity, surface chemistry, route of administration, length of stay in circulation, and reaction with the immune system. Nanostructures exhibit unique physicochemical and biological properties, which makes them a favorable material for biomedical applications. ${ }^{26,29}$ Nanoscale structures, or nanosized structures, can be used to carry drugs such as liposomes, synthetic and natural polymers, inorganic and metal NPs, dendrimers, silica, and carbon materials, as well as magnetic NPs (MNPs) ${ }^{30,31}$ (Figure 2).

\section{Lipid-associated formulations}

Lipid formulations involve the association of an antifungal drug, such as AmB or nystatin, with a lipid delivery system to reduce toxicity. ${ }^{33,34}$ Three different lipid formulations of AmB have been introduced in the clinical setting. The lipid composition and molecular structure of these formulations vary considerably with unique pharmacokinetic profiles.
A

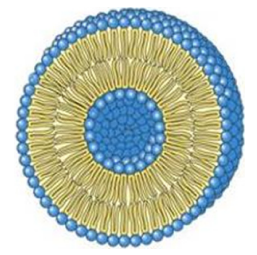

Liposome 80-300 nm

C

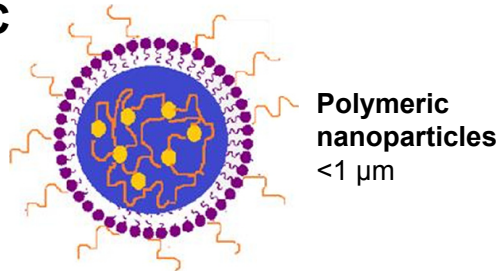

B

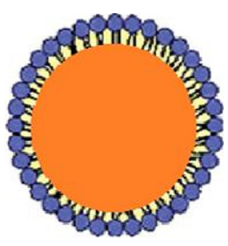

D

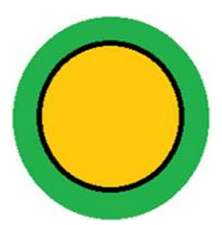

Solid lipid nanoparticles $80-300 \mathrm{~nm}$

Silica; magnetic nanoparticles $100-300 \mathrm{~nm}$

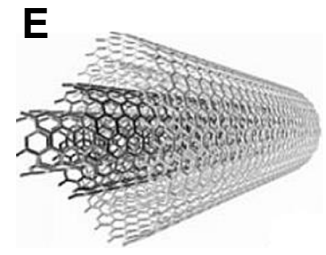

Carbon nanoparticles 1-5 $\mathrm{nm}$ diameter

Figure 2 Nanostructured drug delivery systems modified.

Notes: (A) Liposome. (B) Solid lipid nanporticles. (C) Polymeric nanoparticles. (D) Silica; magnetic nanoparticles. (E) Carbon nanoparticles. 
Although there is evidence of the safety of these formulations, the impact of their unique structure and pharmacokinetic differences for specific clinical efficacy is unproven. ${ }^{35}$

AmB deoxycholate $(\mathrm{D}-\mathrm{AmB})$ is a polyene macrolide available for clinical use since its initial FDA approval in 1959. ${ }^{36}$ AmB is produced through a fermentation process by soil actinomycete Streptomyces nodosus. The AmB has broad spectrum of action and has been considered the gold standard of antifungal therapy for many years, despite being associated with a high incidence of adverse effects related to infusion and nephrotoxicity. ${ }^{36,37} \mathrm{D}$-AmB still has a place in the antifungal therapy but newer drugs (eg, AmB associated with lipid formulations, fluconazole and voriconazole, or caspofungin and micafungin) are being used as first-line treatment options. ${ }^{38}$ Fluconazol represented a major advance in the treatment of invasive candidiasis because of its broad activity, excellent tolerability, and favorable pharmacokinetics. Since its introduction, fluconazole has been widely used for the treatment and prophylaxis of candidiasis, except for those infections caused by C. krusei, C. glabrata, or other species with reduced susceptibility or resistance to this drug. ${ }^{39}$

\section{Lipid complex and colloidal dispersion}

In the late 1990s, almost 40 years after the first formulation of $\mathrm{D}$-AmB, three AmB-based lipid formulations, namely ABLC $\left(\right.$ Abelcet $\left.^{\circledR}\right), \operatorname{ABCD}\left(\right.$ Amphotec $\left.^{\circledR}\right)$, and L-AmB (AmBisome ${ }^{\circledR}$ ) were developed to reduce nephrotoxicity without compromising antifungal efficacy. ${ }^{20,38}$ ABLC (Abelcet ${ }^{\circledR}$; The Liposome Company, Princeton, NJ, USA) received initial approval in the UK in April 1995 and was the first lipid-based formulation approved by the FDA in December 1995. ABCD was previously marketed as both Amphocil ${ }^{\circledR}$ and Amphotec ${ }^{\circledR}$ and was initially approved in the UK in 1994 and by the FDA in December 1996. ${ }^{27}$ The first lipid-based formulation developed was ABLC by associating AmB with a lipiddrug delivery vehicle. ABLC consists of AmB in complex with two phospholipids at 1:1 drug-to-lipid molar ratio. Both phospholipids, 1- $\alpha$-dimyristoylphosphatidylcholine and 1- $\alpha$-dimyristoylphosphatidylglycerol, are present at 7:3 molar ratio. ABLC is characterized by lipid-stabilized AmB aggregates, which appear as ribbon-like structures, with length ranging from $1.6 \mathrm{~nm}$ to $11.1 \mathrm{~nm}$, and because of its size, circulating AmB serum concentrations are lower when compared to $\mathrm{D}-\mathrm{AmB} \cdot{ }^{35} \mathrm{ABCD}$ consists of 1:1 molar ratio of AmB and cholesterol sulfate, a highly organized structure formed by a natural metabolite of cholesterol. A noncovalent complex of $\mathrm{AmB}$ and cholesteryl sulfate forms a tetramer consisting of a hydrophilic and a hydrophobic part.
These add-in spiral arms form a disk-like structure with a diameter of $\sim 122 \mathrm{~nm}$ and thickness of $4 \mathrm{~nm} .{ }^{40}$ Although $\mathrm{ABCD}$ reduces the availability of $\mathrm{AmB}$ in the kidneys reducing the nephrotoxicity, this drug concentration increases in the endothelial reticulum system, ${ }^{41,42}$ as well as the ABLC formulation. ${ }^{35}$ Both $\mathrm{ABCD}$ and $\mathrm{ABLC}$ are quickly endocyted by the endothelial reticulum system and distributed into the tissue. $^{43}$ ABLC formulations demonstrated efficacy against fungi such as Fusarium solani, ${ }^{44}$ Candida dubliniensis, ${ }^{45}$ A. fumigatus, ${ }^{46}$ Aspergillus quadrilineatus, ${ }^{47}$ C. neoformans, ${ }^{48}$ and Rhizopus oryzae. ${ }^{49}$ Table 1 lists the activity of ABCL and $\mathrm{ABCD}$ formulations against different fungi.

ABCD exhibits dose-limiting, infusion-related toxicities; ${ }^{35}$ consequently, the dosages administered should not exceed 3-4 $\mathrm{mg} / \mathrm{kg} / \mathrm{d}$. ABCD formulation was not effective in the treatment of paracoccidioidomycosis with a dosage of $3 \mathrm{mg} / \mathrm{kg} / \mathrm{d}$, the failure of which can possibly be due to dosage, duration, or poor effectiveness of this lipid preparation, ${ }^{50}$ although Hanson and Stevens ${ }^{51}$ reported in vitro activity against Paracoccidiodes brasiliensis. This formulation is not suitable as a prophylactic antifungal agent for neutropenic patients due to adverse effects related to infusion. ${ }^{52} \mathrm{ABCD}$ was found at high concentrations in the lungs after treatment, which does not happen with L-AmB, thus being a possible alternative for lung infections. ${ }^{53}$ The prophylactic use against pulmonary mycoses by $\mathrm{AmB}$ nebulization has been reported. ${ }^{54,55}$ Other drugs, such as itraconazole, in colloidal dispersion could also be suitable for nebulization. ${ }^{56}$

\section{Liposomes}

Liposomes are other type of lipid formulations, consisting of unilamellar or multilamellar layers on the membrane of lipids such as phospholipids, surrounded by aqueous compartment. ${ }^{60,61}$ The liposomes can carry hydrophilic drugs in the aqueous core and increase penetration through the lipophilic membranes, as well as lipophilic drugs, which are inserted into the lipid bilayer, increasing their solubility in aqueous body fluids. ${ }^{68}$ Liposomes provide a better protection than other lipid formulations against external degradation by enzymes. In addition, they are biocompatible and biodegradable. ${ }^{62,63}$

Conventional liposomes have some limitations, such as little instability and difficult to be stored for long periods and rapid uptake by the RES, thereby decreasing their half-life in circulation. ${ }^{69}$ To solve these problems, extensive research has been developed to modify the surface of liposomes, to optimize their size, and to understanding their mechanisms of action. New generation liposomes are characterized by high mechanical stability, ability to induce or to inhibit the 
Table I Effect of AmB formulations ABLC and ABCD with different fungal species

\begin{tabular}{|c|c|c|c|c|c|}
\hline Disease/microorganism & $\begin{array}{l}\text { Treatment } \\
\text { systems }\end{array}$ & $\begin{array}{l}\text { Delivery } \\
\text { properties }\end{array}$ & Pharmacokinetic & Category & References \\
\hline $\begin{array}{l}\text { Different fungal species, including } \\
\text { Paracoccidioides brasiliensis }\end{array}$ & $A m B$ & $A B C D$ & Not reported & In vitro & 51 \\
\hline $\begin{array}{l}\text { Fungal sinusitis } \\
\text { Aspergillus quadrilineatus }\end{array}$ & $A m B$ & $A B C D$ & $\begin{array}{l}\text { Initial dose of } 0.5 \mathrm{mg} / \mathrm{kg} / 10 \mathrm{~d} \\
\text { Increased gradually by } 0.5 \mathrm{mg} / \mathrm{kg} \\
\text { every } 3 \text { days until a maximal } \\
\text { dose of } 2.5 \mathrm{mg} / \mathrm{kg}\end{array}$ & Case study & 47 \\
\hline Disseminated cryptococcosis & $A m B$ & $\begin{array}{l}A B C D \text { versus } \\
D-A m B\end{array}$ & $0.8 \mathrm{mg} / \mathrm{kg}$ & Murine & 57 \\
\hline Mucormycosis & $A m B$ & $A B C D$ & Not reported & Case study & 58 \\
\hline Liver transplant recipient & $A m B$ & $A B C D+I T Z$ & Not reported & Case study & 59 \\
\hline Phaeohyphomycosis & ITZ & $A B C D+I T Z$ & Not reported & Case study & 59 \\
\hline $\begin{array}{l}\text { Bone marrow transplant patients with } \\
\text { invasive fungal infections }\end{array}$ & $A m B$ & $A B C D$ & $7.5 \mathrm{mg} / \mathrm{kg}$ & Human & 60 \\
\hline $\begin{array}{l}\text { Lung transplant recipient with Fusarium } \\
\text { solani infection }\end{array}$ & $A m B$ & ABLC & $5 \mathrm{mg} / \mathrm{kg} / \mathrm{d}$ & Case study & 44 \\
\hline Immunocompromised patients with candidemia & $A m B$ & $A B C D$ & $3.9 \mathrm{mg} / \mathrm{kg}$ & Human & 61 \\
\hline Meningitis by Cryptococcus neoformans & $\begin{array}{l}\text { AmB } \\
\text { Flucytosine } \\
\text { Fluconazole }\end{array}$ & $A B C D$ & $\begin{array}{l}5.0-7.5 \mathrm{mg} / \mathrm{kg} \text { combined with } \\
\text { flucytosine at } 20-60 \mathrm{mg} / \mathrm{kg} / \mathrm{d} \text { and } \\
\text { fluconazole at } 30-40 \mathrm{mg} / \mathrm{kg} / \mathrm{d}\end{array}$ & Murine & 48 \\
\hline Rhinocerebral mucormycosis & $A m B$ & $A B C D$ & $\begin{array}{l}5 \mathrm{mg} / \mathrm{kg} / \mathrm{d} \\
4 \mathrm{mg} / \mathrm{kg} / \mathrm{d} \\
6 \mathrm{mg} / \mathrm{kg} / \mathrm{d}\end{array}$ & Case study & 62 \\
\hline Mucormycosis & $A m B$ & ABLC & $5 \mathrm{mg} / \mathrm{kg} / \mathrm{d}$ & Case study & 63 \\
\hline Candida dubliniensis & $A m B$ & $\begin{array}{l}\text { ABLC } \\
A B C D \\
\text { L-AmB }\end{array}$ & $\begin{array}{l}\text { Not reported } \\
\text { Not reported } \\
\text { Not reported }\end{array}$ & $\begin{array}{l}\text { In vitro } \\
\text { In vitro } \\
\text { In vitro }\end{array}$ & $\begin{array}{l}45 \\
45 \\
45\end{array}$ \\
\hline Mucormycosis & $A m B$ & $A B C D$ & $4.8 \mathrm{mg} / \mathrm{kg}$ & Human & 60 \\
\hline Invasive aspergillosis & $A m B$ & $A B C D$ & $6 \mathrm{mg} / \mathrm{kg} / \mathrm{d}$ & Human & 64 \\
\hline Aspergillus fumigatus & $A m B$ & ABLC & $5 \mathrm{mg} / \mathrm{kg}$ once daily $\times 4$ days & Rats & 46 \\
\hline $\begin{array}{l}\text { Lung transplant recipients with invasive } \\
\text { aspergillosis }\end{array}$ & $A m B$ & ABLC & Not reported & Prophylactic use & 54 \\
\hline Coccidioidal meningitis by Coccidioides immitis & $A m B$ & $\begin{array}{l}\text { ABLC versus } \\
D-A m B\end{array}$ & $\begin{array}{l}\text { D-AmB I mg/kg } \\
\text { ABLC } 7.5 \mathrm{mg} / \mathrm{kg} \text { or } 15 \mathrm{mg} / \mathrm{kg}\end{array}$ & Rabbit & 65 \\
\hline Cholestatic liver disease and fungal infection & $A m B$ & $A B C D$ & $4 \mathrm{mg} / \mathrm{kg}$ & Case study & 66 \\
\hline $\begin{array}{l}\text { Acute myeloblastic leukemia and Rhizopus } \\
\text { oryzae infection }\end{array}$ & $A m B$ & $A B C D$ & $\mathrm{I} \times 400 \mathrm{mg} / \mathrm{d}$ & Case study & 49 \\
\hline $\begin{array}{l}\text { Liver transplant recipients with invasive fungal } \\
\text { infections }\end{array}$ & $A m B$ & $A B C D$ & Not reported & Prophylactic use & 67 \\
\hline
\end{tabular}

Abbreviations: AmB, amphotericin B; ABLC, amphotericin B lipid complex; ABCD, amphotericin B colloidal dispersion; D-AmB, AmB deoxycholate; ITZ, itraconazole; L-AmB, liposomal AmB.

immune system, longer bypass, high loading efficiency, ease of interaction with the cell membrane, and increased target specificity. The milestone in the development of the new generation of liposomes is to control drug release. ${ }^{68}$

Indeed, the progress in pharmacology has introduced a number of potent therapeutic agents requiring drug carriers that are selective and bioresponsive. Advances in the technology of liposomes as drug delivery systems include long-circulating liposomes, for example, liposomes prepared with hydrophilic polymers on their surface (eg, polyethylene glycol), reduce both uptake by reticuloendothelial system and toxicity of the encapsulated drug. ${ }^{64,70}$ This camouflage allows liposomes to exhibit the abovementioned functions. However, there is the disadvantage of an inhibited cellular absorption, limiting their uptake by macrophages and tumor cells. Hatakeyama et $\mathrm{al}^{71}$ developed cleavable polyethylene glycol (PEG)-lipids to solve the problem of cellular uptake inhibition, since PEG systems are separated in response to the target tissue microenvironment. The target specificity is achieved by anchoring targeting ligands that bind to the desired receptors. ${ }^{72}$ The number of plates or cross-linking lipids controls the rate of drug release from liposomes. ${ }^{73}$ Approximately 50 years after the discovery of liposomes, the FDA approved 13 liposome-based products for human 
use, which includes one formulation containing $\mathrm{AmB}$ for the treatment of fungal infections. ${ }^{68}$

L-AmB presents significantly lower toxicity compared to other AmB formulations, and it is effective in the treatment of severe invasive mycoses, including mucormycosis, ${ }^{74}$ fusariosis, ${ }^{75}$ cryptococcal meningitis, ${ }^{76,77}$ coccidioidal meningitis, ${ }^{78,79}$ blastomycosis, ${ }^{80}$ and pulmonary aspergillosis. ${ }^{81,82}$ However, in 2013, Ariano et $\mathrm{a}^{83}$ reported that L-AmB may not be adequate to control lung infections by Blastomyces dermatitidis. Al Nakeeb et al ${ }^{82}$ found that lipid formulations of $\mathrm{AmB}$ can induce dose-dependent reduction in lung injury markers and circulating fungal biomarkers. The recommended therapeutic dosages are 3-6 mg/kg/d. ${ }^{35}$ A clinical dose of L-AmB $3 \mathrm{mg} /$ $\mathrm{kg} / \mathrm{d}$ may cause complete suppression of both galactomannan and levels of $1,3-\beta$-D-glucan in most patients with invasive aspergillosis. ${ }^{82}$

The literature reports some problems associated with administration of L-AmB, such as hepatotoxicity, ${ }^{84}$ progressive leukoencephalopathy, ${ }^{85,86}$ and also development of lysosomal storage disease. ${ }^{87}$ Treatment failures have also been reported. ${ }^{88,89}$ The prophylactic use of L-AmB in immunocompromised patients is still a challenge. Mihara et $\mathrm{a}^{90}$ report that prophylaxis with aerosolized L-AmB was not effective in animal model. Therefore, prospective studies are needed to compare this formulation with triazoles. In addition to AmB, other antifungal agents are carried by liposomal delivery systems, such as nystatin. ${ }^{33,34} \mathrm{~L}-\mathrm{AmB}$ could be useful for the treatment of cryptococcosis, ${ }^{91}$ including species of Aspergillus, ${ }^{92}$ C. dubliniensis. ${ }^{45}$

L-AmB also has activity against fungal biofilms. Schinabeck et $\mathrm{al}^{94}$ were the first to describe Candida biofilm infection of catheters in animal models treated with L-AmB to block the infection. In addition, $\mathrm{L}-\mathrm{AmB}$ was effective to eradicate Candida biofilm in a continuous catheter flow model, ${ }^{95}$ and Ramage et a ${ }^{96}$ showed that $\mathrm{L}-\mathrm{AmB}$ kills $C$. albicans biofilms rapidly and effectively in a dose-dependent manner.

The need to improve treatment outcomes for IFI increased interest in exploring an alternative antifungal strategy. The administration of AmB in aerosol, which has been widely used, to provide the drug directly to the site of infection or fungal colonization, has the potential to maximize their spectrum of activity while minimizing systemic toxicity that is associated with parenteral administration. Aerosol AmB is used (usually as a prophylactic strategy) in high-risk patients. ${ }^{97}$ The literature reports few studies regarding delivery systems based on aerosol for fungal infections, including AmB to prevent pulmonary aspergillosis, ${ }^{98}$ C. neoformans, ${ }^{89}$ and C. albicans. ${ }^{99}$

Table 2 shows the studies with L-AmB and L-AmB formulations associated with other conventional antifungal drugs for the treatment of IFIs in immunocompromised patients, including studies on in vitro activity of L-AmB against different fungi.

In addition to the liposomal preparation of $\mathrm{AmB}$, there are AmB-polyaggregates with similar efficacy to that of D-AmB and $\mathrm{L}-\mathrm{AmB}$ in the treatment of a murine-disseminated infection by $C$. glabrata. ${ }^{120}$ Souza et al ${ }^{129}$ tested an alternative delivery system to D-AmB, the NANO-D-AmB that has antifungal efficacy against $P$. brasiliensis with lower levels of cytotoxicity compared to that of $\mathrm{D}-\mathrm{AmB}$ formulation both in vivo and in vitro, thus confirming a better delivery of AmB.

\section{NPs based on solid lipid nanoparticles and nanostructured lipid carriers}

Solid lipid nanoparticles (SLNs) emerged as a new class of colloidal drug carriers at the beginning of the 1990s, and their application has been widely exploited as drug delivery in the area of pharmaceutics, clinical medicine, and therapy. Polymeric NPs (PNPs) have the advantage of promoting chemical modifications, but there are some limitations such as polymer degradation, high cost, and difficult approval by regulatory authorities. ${ }^{130}$ Thus, the attention of several research groups has been focused on an alternative to PNPs, that is, the SLNs. ${ }^{131}$ SLNs provide physical stability as incorporated drugs do not suffer degradation, have controlled release, and excellent tolerability. Therefore, they can be used by different routes of administration, such as parenteral, ${ }^{132}$ peroral, ${ }^{133}$ dermal, ${ }^{134}$ ocular, ${ }^{135}$ pulmonary, ${ }^{136}$ and rectal. ${ }^{137}$

SLNs are a generation of drugs where the liquid lipid (oil) has been replaced by a solid lipid, mainly composed of a dispersed lipid in physiological water or aqueous surfactant solution (Figure 3). Replacement of liquid lipid by solid lipid represents a milestone for drug controlled release because the mobility of the drug within the solid lipid is usually lower than within the liquid oil, which makes this system performance attractive for pharmaceutical products. ${ }^{131}$

The most advanced forms of SLNs are nanostructured lipid carriers (NLCs), lipid-drug conjugates, and polymer lipid hybrid nanoparticles (PLNs). Therefore, NLCs, introduced at the millennium's turn, are made of a solid lipid matrix that traps the liquid lipid in their nanocompartments, ${ }^{138}$ which decreases some of the problems associated with SLNs, such as limited drug-loading capacity, expulsion of the drug during storage, suitability of drug release, and physical stability of long-term suspension. ${ }^{131}$ Lipid-drug conjugates were developed to increase the drug-loading capacity, whereas PLNs are hybrids of liposome and PNPs developed to carry poorly water-soluble drugs with high encapsulation efficiency and loading capacity and to control the release 
Table 2 Liposomes in fungal diseases

\begin{tabular}{|c|c|c|c|}
\hline Disease/microorganisms & Treatment & Category & References \\
\hline Systemic candidiasis & L-AmB & Mouse & 100 \\
\hline Hematologic malignancies & L-AmB & Human & 93,101 \\
\hline Hematologic malignancies and invasive sino-nasal aspergillosis & L-AmB & Human & 102 \\
\hline Candida albicans & L-AmB & In vitro & 88 \\
\hline Inhibition of HIV replication & L-AmB & Human & 103 \\
\hline Heart transplant and transplant pulmonary & L-AmB & Human & 104 \\
\hline Aspergillosis liver transplant & L-AmB & Human & 105,106 \\
\hline Lymphoblastic leukemia and fusariosis & L-AmB & Human & 107 \\
\hline \multirow[t]{2}{*}{ Rhinocerebral and rhino-orbital mucormycosis } & L-AmB & Human & $108-110$ \\
\hline & L-AmB + micafungin & & \\
\hline Cryptococcus neoformans & Aerosolized L-AmB & Mouse & 89 \\
\hline Transplant recipients & L-AmB (AmBisome) & Human & 105 \\
\hline Liver transplant and Rhizopus sinusitis & L-AmB & Human & 111 \\
\hline Blastomycosis & L-AmB & Murine & 80 \\
\hline AIDS and cryptococcosis & L-AmB & Human & 112 \\
\hline C. albicans & Aerosolized L-AmB & Mouse & 98 \\
\hline Cardiac mycetomas & L-AmB + fluconazole & Human & 113 \\
\hline Invasive candidiasis & L-AmB + caspofungin & Murine & 114 \\
\hline Catheter antifungal lock & L-AmB & Human & 115 \\
\hline Exophiala dermatitidis & L-AmB & Murine & 116 \\
\hline Fusarium verticillioides & L-AmB + terbinafine & Murine & 117 \\
\hline C. albicans biofilm & L-AmB & Rabbit & 93 \\
\hline C. albicans biofilm & & In vitro & 94 \\
\hline C. albicans and bloodstream isolates biofilms & & Human & 95 \\
\hline Intraventricular cryptococcoma & L-AmB + voriconazole & Case study & 118 \\
\hline Kidney transplant & L-AmB & Case study & 119 \\
\hline Esophageal histoplasmosis & Itraconazole & & \\
\hline Cerebral aspergillosis by Aspergillus fumigatus & L-AmB & Case study & 120 \\
\hline Invasive pulmonary aspergillosis & Nebulized L-AmB & Prophylaxis & 92 \\
\hline Kidney transplant and mucormycosis (Rhizopus microsporus) & L-AmB + posaconazole & Case study & 121 \\
\hline Leukemia and pulmonary mucormycoses & L-AmB & & 122 \\
\hline Hematologic malignancies and IFls & L-AmB & Prophylaxis & 123 \\
\hline Liver transplant and IFls & L-AmB & Prophylaxis & 106 \\
\hline Vertebral infection by $C$. albicans & L-AmB + flucytosine & Case study & 124 \\
\hline Disseminated aspergillosis & L-AmB + erythropoietin & Mouse model & 125 \\
\hline Invasive aspergillosis by $A$. fumigatus & L-AmB & Rabbit & 82 \\
\hline Pulmonary aspergillosis & Nebulized L-AmB & Human & $126-128$ \\
\hline
\end{tabular}

Abbreviations: C. albicans, Candida albicans; L-AmB, liposomal amphotericin B; A. fumigatus, Aspergillus fumigates; IFI, invasive fungal infection.

of drugs. Moreover, PLNs show excellent serum stability and a wide spectrum of different target cells. ${ }^{139,140}$ The presence of a solid lipid matrix can cause problems in the production of SLNs, since this matrix system is subject to crystallization during its formation, resulting in some drawbacks such

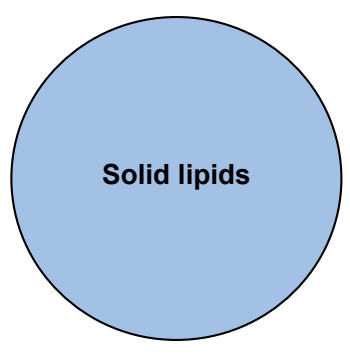

SLN
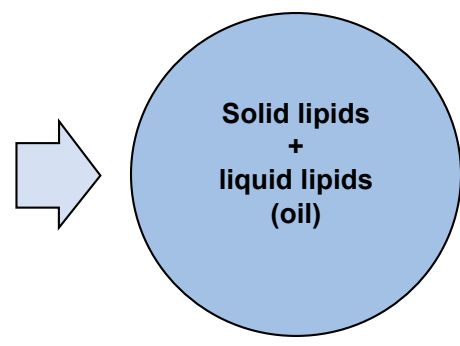

NLC
Figure 3 Nanoparticles based on solid lipid nanoparticles (SLNs) and nanostructured lipid carriers (NLCs). as a low encapsulation efficiency and a poor expulsion of the stored drug. ${ }^{141-143}$ Table 3 shows some studies on SLN transport systems in antifungal therapy for the therapy of fungal infections. However, scientific evidence on infection treated with the SLN system is scarce.

NLCs are produced by a lipid mixture of liquid and solid phases with increased content of NPs. ${ }^{27}$ Mathpal et a ${ }^{144}$ have recently conducted a study using a spraying technique for pulmonary delivery of AmB-NCL and concluded that through this technique the drugs are better distributed throughout the lung tissue. Several antifungal agents were also tested in different SLN and NLC delivery systems, such as itraconazole-loaded SLNs, ${ }^{130,145}$ itraconazole-loaded NLC, ${ }^{146,147}$ miconazole nitrate-loaded NLC, ${ }^{148}$ econazole nitrate-loaded NLC, ${ }^{149}$ and voriconazole ${ }^{150}$ (Table 3). PNPs and nanosuspensions would present clear advantages over 
Table 3 Antifungal drugs-loaded nanoparticles based on solid lipids (SLNs) and nanostructured lipid carriers (NLCs)

\begin{tabular}{|c|c|c|c|c|c|}
\hline Disease/microorganism & Treatment & Delivery systems & Size & Category & References \\
\hline Candidiasis & Miconazole nitrate (MN) & $\mathrm{MN} / \mathrm{SLN}$ & $206.39 \pm 9.37 \mathrm{~nm}^{\mathrm{a}}$ & Rats & 152 \\
\hline \multirow[t]{2}{*}{ Cutaneous candidiasis } & Fluconazole (FLZ) & SLN/FLZ & $178 \mathrm{~nm}$ & Rats & 153 \\
\hline & & NLC/FLZ & $134 \mathrm{~nm}$ & Rats & 153 \\
\hline Fungal vaginal & Clotrimazole (CTZ) & CTZ-NLC-gel & NA & In vitro & 154 \\
\hline C. albicans & Miconazole & $\begin{array}{l}\text { Encapsulation of miconazole in } \\
\text { the NLC }\end{array}$ & $200 \mathrm{~nm}$ & In vitro & 155 \\
\hline Cutaneous candidiasis & FLZ-loaded SLN & FLZ/SLN & $178.9 \pm 3.8 \mathrm{~nm}^{\mathrm{a}}$ & In vitro/in vivo & 156 \\
\hline C. albicans & $\begin{array}{l}\text { SLNs of terbinafine } \\
\text { hydrochloride }(\mathrm{TH})\end{array}$ & $\begin{array}{l}\text { SLNs were incorporated into } \\
\text { Carbopol gel }\end{array}$ & $300 \mathrm{~nm}$ & In vivo & 157 \\
\hline $\begin{array}{l}\text { Vaginal infection - } \\
\text { C. albicans }\end{array}$ & Ketoconazole (KTZ) and CTZ & $\begin{array}{l}\text { SLNs based on polyoxyethylene- } \\
40 \text { stearate (PEG- } 40 \text { stearate) for } \\
\text { the administration of such as KTZ } \\
\text { and CTZ antifungal agents }\end{array}$ & NA & In vitro & 158 \\
\hline Aspergillus flavus & $\begin{array}{l}\text { Itraconazole into solid lipid } \\
\text { nanoparticles (SLNs) for } \\
\text { topical ocular delivery }\end{array}$ & $\begin{array}{l}\text { ITZ/SLNs stearic acid and palmitic } \\
\text { acid }\end{array}$ & $\begin{array}{l}\text { 139-199 nm } \\
\text { (stearic acid) } \\
\text { I26-160 nm } \\
\text { (palmitic acid) }\end{array}$ & In vitro & 145 \\
\hline Pulmonary aspergillosis & $\begin{array}{l}\text { Lipidic nanoparticles of } \\
\text { amphotericin B were prepared } \\
\text { by spray drying technique } \\
\text { using hydroxypropylmethyl- } \\
\text { cellulose (HPMC) }\end{array}$ & AmB/NLC spray drying & $600-700 \mathrm{~nm}$ & In vivo & 144 \\
\hline
\end{tabular}

Note: a Data shown as mean \pm standard deviation.

Abbreviations: AmB, amphotericin B; C. albicans, Candida albicans; NA, not available.

lipid formulations, since they have a longer shelf life at room temperature and low production costs. ${ }^{151}$

\section{Polymeric NPs}

PNPs are polymeric colloidal systems, which have a diameter $<1 \mu \mathrm{m}$, in which the drug can be dissolved, coated, encapsulated, or dispersed. ${ }^{29,159}$ Polymer degradation, high cost, and difficult approval by regulatory authorities are some of the disadvantages. ${ }^{131}$ PNPs are stable in the gastrointestinal environment and protect encapsulated drugs against gastrointestinal $\mathrm{pH}$, degradation enzymes, and efflux pumps, maintaining the stability of the drugs in this unfavorable environment. ${ }^{160}$ The use of polymers to form PNPs provides flexibility due to their physicochemical properties (eg, size, surface charge, and hydrophobicity), allowing a controlled drug release. In addition, it is possible to modulate the surface properties or use different polymer conjugates on the surface of PNPs. ${ }^{161}$ The possibility to add antibodies, peptides, or small molecules to the polymer surface allows tissuespecific interactions with cell receptors or components. ${ }^{162}$ Moreover, PNPs enable the encapsulation of a broad range of therapeutic drugs and molecules, such as DNA and small interfering RNA. ${ }^{160}$

PNPs are classified into two categories: nanospheres and nanocapsules. Nanocapsules are vesicular systems in which the drug is inside an aqueous or oily cavity surrounded by a polymeric membrane, whereas nanospheres are matrix systems in which the drug is physically and uniformly dispersed in the matrix. ${ }^{163}$ These delivery systems have been developed primarily for parenteral, oral, or ocular administration. There are several polymers for preparing PNPs, such as poly- $\varepsilon$-caprolactone, ${ }^{164}$ polyacrylamide,${ }^{165}$ polyacrylate, ${ }^{166}$ DNA, ${ }^{167}$ chitosan, ${ }^{167-169}$ and gelatin. ${ }^{170}$ After a polymerization reaction, drugs may be immobilized on the surface of the $\mathrm{PNPs}^{171}$ or encapsulated in their structure during the polymerization processing. ${ }^{172}$ The release of the drug may occur by desorption, diffusion, or erosion of PNPs in the target tissue. ${ }^{29}$ However, during the storage time, aggregation of NPs can occur and form precipitates. Other chemical stability problems regarding the polymer or other raw materials have been described, which obstruct their industrial applicability. ${ }^{173}$

Inorganic NPs, including gold, iron oxide, silver, or silica, among others, are investigated in preclinical and clinical studies for the treatment, diagnosis, and detection of many diseases. Moreover, many inorganic compounds serving as the material for making NPs have been widely used in clinical practice for several therapeutic applications. ${ }^{174}$ One example of therapeutic compounds that act as antibacterial agents is silver ions. ${ }^{175-177}$ Inorganic NPs offer diagnostic and therapeutic opportunity that other PNPs or not, cannot offer. ${ }^{174}$

PNPs have some problems arising from residues of organic solvents used in the production process, such as 
cytotoxicity of the polymer and complex production for industrial application. In many production processes, the concentration of NPs is low not exceeding $2 \%,{ }^{178}$ which compromises their use. Thus, the development of solid dosage forms of NPs is a point of interest in research. Examples of antifungal agents and metal particles associated with PNPs used as drug delivery systems are shown in Table 4.

\section{Dendrimers}

Dendrimers present synthetic polymeric architectures with low polydispersion and controlled surface features. Dendrimers have three main architectural components, namely, core, dendrons, and surface-active groups. ${ }^{196,197}$ There are some ways to connect biologically active compounds to dendrimers: the drug can be encapsulated in the internal structure of the dendrimers ${ }^{198}$ or chemically linked or physically adsorbed onto the surface of them. ${ }^{199}$ The choice of the immobilization method will depend on the characteristics of the drug.

Several families of dendrimers have been widely studied regarding their use in biomedical sciences. Most well-known dendrimers include polyamidoamines, polypropyleneimines, poly-L-lysines, carbosilanes, and phosphorous dendrimers. Their properties are often not satisfactory because of the high cytotoxicity of the nanomolecules and their low solubility and biocompatibility. Thus, dendrimers are often subjected to various modifications in order to improve their features: dendrimer conjugate with $\mathrm{PEG},{ }^{200}$ carbohydrates, ${ }^{201}$ or acetyl groups ${ }^{202}$ to reduce the cytotoxicity. The compounds bound to dendrimers can improve the surface activity as well as their biological and physical properties. Several specific ligands can be adsorbed, including folic acid, ${ }^{203}$ antibodies, ${ }^{204}$ target cyclic peptides containing arginine-glycine-aspartic acid, ${ }^{205}$ and PEG. ${ }^{206}$

Table 4 Polymeric and other nanoparticles with antifungal activity

\begin{tabular}{|c|c|c|c|c|}
\hline $\begin{array}{l}\text { Disease/ } \\
\text { microorganism }\end{array}$ & Treatment & Delivery systems/methods/size & Category & References \\
\hline C. albicans & $\begin{array}{l}\text { AmB, } 5 \text {-fluorocytosine } \\
\text { or rapamycin }\end{array}$ & $\begin{array}{l}\text { Encapsulated in I,2-distearoyl-sn-glycero-3-phosphoethanolamine- } N \text { - } \\
\text { methoxy poly(ethylene glycol) (PEG-DSPE) micelles }\end{array}$ & In vitro & 179 \\
\hline C. albicans & $A m B$ & $\begin{array}{l}\text { Poly(2-ethyl-2-oxazoline)-block-poly(aspartic acid) (PEOz-b-PAsp)/ } \\
\text { micelles }\end{array}$ & In vitro & 180 \\
\hline Paracoccidioides & Peptide & Poly(lactic acid-glycolic acid) (PLGA) & In vitro & 181 \\
\hline Cryptococcal meningitis & $\begin{array}{l}\text { PI0 (PLGA) } \\
\text { nanoparticles }\end{array}$ & $\begin{array}{l}\text { Amphotericin B (AmB)-polybutylcyanoacrylate nanoparticles } \\
\text { (AmB-PBCA-NPs) modified with polysorbate } 80: 69.0 \pm 28.6 \mathrm{~nm}\end{array}$ & Mice & 182 \\
\hline A. flavus & ITZ and coumarin & $\begin{array}{l}\text { ITZ and coumarin-6 loaded polylactic-co-glycolic acid-nanoparticles } \\
\text { (PLGA-ITZ) and PLGA-C6-NPs): } 232 \mathrm{~nm}, 630 \mathrm{~nm} \text { and I,060 nm }\end{array}$ & In vitro & 183 \\
\hline P. brasiliensis & ITZ & PLGA-dimercaptosuccinic acid (DMSA) nanoparticles: $174 \pm 86 \mathrm{~nm}$ & In vitro & 184 \\
\hline $\begin{array}{l}\text { A. niger and Fusarium } \\
\text { oxysporum }\end{array}$ & Not applicable & $\begin{array}{l}\text { Surface-modified sulfur nanoparticles (SNPs)/polyethylene glycol-400 } \\
\text { (PEG-400) }\end{array}$ & In vitro & 185 \\
\hline C. albicans & $A m B$ & $\begin{array}{l}\text { Poly(epsilon-caprolactone) (PCL) and poly(N,N-dimethylamino-2-ethyl } \\
\text { methacrylate) (PDMAEMA), or methoxy polyethylene glycol (PEG) }\end{array}$ & In vitro & 186 \\
\hline C. albicans biofilm & Not applicable & $\begin{array}{l}\text { Silicone catheter, polyvinyl chloride (PVC), and glass coated with } \\
\text { titanium dioxide }\left(\mathrm{TiO}_{2}\right) \text { nanoparticles: } 70-100 \mathrm{~nm}\end{array}$ & In vitro & 187 \\
\hline $\begin{array}{l}\text { C. neoformans - } \\
\text { meningoencephalitis }\end{array}$ & $A m B$ & Angiopep-PEG-PE/AmB polymeric micelles & Murine & 188 \\
\hline $\begin{array}{l}\text { C. albicans, A. fumigatus, } \\
\text { and Trichophyton rubrum }\end{array}$ & $A m B$ & $\begin{array}{l}\text { Poly(D,L-lactide-co-glycolide) (PLGA) nanoparticles (NPs) } \\
\text { and nanosuspensions }\end{array}$ & Mouse & 189 \\
\hline $\begin{array}{l}\text { Corneal fungal infections } \\
\text { (Flu-CNGs) }\end{array}$ & FLZ & FLZ-loaded chitin nanogels & In vitro & 190 \\
\hline $\begin{array}{l}\text { A. flavus and Aspergillus } \\
\text { terreus }\end{array}$ & Silver nanoparticles & $\begin{array}{l}\text { Silver nanoparticle-encapsulated functionalized chitosan was prepared } \\
\text { by the phase transfer method }\end{array}$ & In vitro & 191 \\
\hline C. albicans and C. glabrata & CTZ & CTZ-loaded cationic nanocapsules using Eudragit ${ }^{\circledR}$ RSI00: I44 nm & In vitro & 192 \\
\hline C. albicans & CTZ & CLZ-loaded nanovesicular carriers (ocular nanovesicular carrier) & In vitro & 193 \\
\hline $\begin{array}{l}\text { C. albicans and C. glabrata } \\
\text { biofilm }\end{array}$ & Silver nanoparticles & Not applicable & In vitro & 176 \\
\hline C. albicans and C. glabrata & CTZ & $\begin{array}{l}\text { Coconut oil-core nanocapsules prepared from Eudragit }{ }^{\circledR} \text { RSI00: } \\
200 \mathrm{~nm}\end{array}$ & In vitro & 194 \\
\hline C. albicans & Not applicable & Polyethyleneimine (PEI) and PEI-based nanoparticles (nano-PEI) & In vitro & 195 \\
\hline C. albicans biofilm & Silver nanoparticles & Not applicable & In vitro & 177 \\
\hline
\end{tabular}

Abbreviations: C. albicans, Candida albicans; AmB, amphotericin B; ITZ, Itraconazole; A. flavus, Aspergillus flavus; P. brasiliensis, Paracoccidiodes brasiliensis; A. niger, Aspergillus niger; C. neoformans, Cryptococcus neoformans; CTZ, Clotrimazole; C. glabrata, Candida glabrata. 
There are few studies on the antifungal activity enhanced by dendrimers. Polyamidoamine dendrimers were shown to improve the solubility of clotrimazole and enhance its antifungal activity against different species of Candida. ${ }^{207}$ According to Janiszewska et al, ${ }^{208}$ the antifungal activity of dendrimeric lipopeptides causes morphological changes in fungal cells and inhibition of enzyme activity candidal 1,3$\beta$-D-glucan synthase. Staniszewska et $\mathrm{al}^{209}$ reported in vitro effects of the dendrimer D186 on the virulence factors of C. albicans, where there was a reduction in adhesive properties and potential of the pathogenic yeast.

\section{Other delivery systems}

The antifungal activity in other delivery systems, such as carbon nanotubes, MNPs, and silica NPs, has been less studied. Carbon nanotubes have been one of the most exploited biomedical applications of NPs in the world. Benincasa et $\mathrm{al}^{210}$ showed that $\mathrm{AmB}$ conjugated to carbon nanotubes presented an excellent activity against clinical isolates of Candida spp. The antimicrobial activity against bacteria and fungi (C. albicans) was also demonstrated by scanning electron microscopy, showing that microbial cells were wrapped or entrapped by carbon nanotube networks. ${ }^{211}$ Reduced graphene oxide nanosheets have antifungal activity against Aspergillus niger, Aspergillus oryzae, and Fusarium oxysporum. ${ }^{212}$ In 2014, Ciu et $\mathrm{al}^{213}$ showed graphene oxide as a novel two-dimensional nanomaterial for applications in health biomedical with antifungal properties and low cost.

Hussein-Al-Ali et $\mathrm{al}^{214}$ demonstrated the antimicrobial activity of MNPs loaded with ampicillin to form a nanocomposite decreases the activity of $C$. albicans. Niemirowicz et $\mathrm{a}^{215}$ also reported an inhibition of the growth of C. albicans by using MNPs that can be removed from human plasma, blood, serum, and abdominal and cerebrospinal fluids.

\section{Conclusion and future prospects}

There is a clear need to find new therapeutic alternatives for IFIs as the number of drugs is reduced and there is an increased resistance to antifungal agents, mainly in emerging fungi such as non-C. albicans species. Moreover, many of the current drugs show toxicity. Thus, a major disadvantage of the polyene antifungal agents, such as $\mathrm{D}-\mathrm{AmB}$, is their clinically significant toxicity, although the development of lipid formulations of $\mathrm{AmB}$ has reduced this problem. ${ }^{35}$ Lipid formulations of $\mathrm{AmB}$ preserve renal function and survival of critically ill patients suffering from IFIs. However, these formulations are very expensive and are not globally available. ${ }^{216}$
Studies involving nanotechnology and medically important fungi have demonstrated improvements in the antifungal properties, such as bioavailability, toxicity, and target tissue, for some drugs, such as AmB, which can facilitate innovative therapeutic approaches. Nanotechnology offers the possibility of multifunctional systems to meet the many different biological and therapeutic requirements. ${ }^{85}$ The ultimate therapeutic goal will be to select a drug that can effectively cure the disease without causing side effects. ${ }^{217}$ In the near future, the use of nanosystems for drug delivery can be attractive strategies for delivering peptides, nuclear acids, or drugs. ${ }^{218}$ In addition, mucoadhesive systems can promote a more specific targeting and retention of the delivery system in humans, such as mucosal surfaces, gastrointestinal tract, lung, genitourinary tract, nasal, and ocular systems. In combination with excellent technological platforms, nanotechnological strategies can increase the bioavailability of antifungal drugs. ${ }^{188}$

\section{Acknowledgments}

This work was financially supported by Fundação de Amparo à Pesquisa do Estado de São Paulo (FAPESP), Conselho Nacional de Desenvolvimento Científico e Tecnológico (CNPq), and Programa de Apoio ao Desenvolvimento Científico - Faculdade de Ciências Farmacêuticas UNESP (PADC-FCF).

\section{Disclosure}

In the past 5 years, Guillermo Quindós has received grant support from Astellas Pharma, Gilead Sciences, Pfizer SLU, Schering Plough, and Merck Sharp and Dohme. He has been an advisor/consultant to Merck Sharp and Dohme and has been paid for talks on behalf of Abbvie, Astellas Pharma, Esteve Hospital, Gilead Sciences, Merck Sharp and Dohme, and Pfizer SLU. The authors have no other relevant affiliations or financial involvement with any organization or entity with a financial interest in or financial conflict with the subject matter or materials discussed in the manuscript, apart from those disclosed.

\section{References}

1. Perlroth J, Choi B, Spellberg B. Nosocomial fungal infections: epidemiology, diagnosis, and treatment. Med Mycol. 2007;45(4):321-346.

2. Alangaden GJ. Nosocomial fungal infections: epidemiology, infection control, and prevention. Infect Dis Clin North Am. 2011;25(1):201-225.

3. WHO. Options for Action. Geneva: WHO Publication; 2012.

4. Sardi Jde C, Pitangui NDS, Rodríguez-Arellanes G, Taylor ML, FuscoAlmeida AM, Mendes-Giannini MJS. Highlights in pathogenic fungal biofilms. Rev Iberoam Micol. 2014;31(1):22-29. 
5. Pelgrift RY, Friedman AJ. Nanotechnology as a therapeutic tool to combat microbial resistance. Adv Drug Deliv Rev. 2013;65(13-14): 1803-1815.

6. Dorgan E, Denning DW, McMullan R. Burden of fungal disease Ireland. J Med Microbiol. 2015;64(pt 4):423-426.

7. Chander J, Stchigel AM, Alastruey-Izquierdo A, et al. Fungal necrotizing fasciitis, an emerging infectious disease caused by Apophysomyces (Mucorales). Rev Iberoam Micol. 2015;32(2):93-98.

8. Brown GD, Denning DW, Gow NA, Levitz SM, Netea MG, White TC. Hidden killers: human fungal infections. Sci Transl Med. 2012;4(165): 165 rv13.

9. Bitar D, Lortholary O, Le Strat Y, et al. Population-based analysis of invasive fungal infections, France, 2001-2010. Emerg Infect Dis. 2014;20(7): 1149-1155.

10. WHO. Antimicrobial Resistance Global Report on Surveillance 2014. Geneva: WHO; 2014.

11. Ruhnke M. Antifungal stewardship in invasive Candida infections. Clin Microbiol Infect. 2014;20(suppl 6):11-18.

12. Voltan AR, Fusco-Almeida AM, Mendes-Giannini MJS. Candiduria: epidemiology, resistance, classical and alternative antifungals drugs. SOJ Microbiol Infect Dis. 2014;2(2):1-7.

13. Schaal JV, Leclerc T, Soler C, et al. Epidemiology of filamentous fungal infections in burned patients: a French retrospective study. Burns. 2015;41(4):853-863.

14. Quindós G. Epidemiology of candidaemia and invasive candidiasis. A changing face. Rev Iberoam Micol. 2014;31(1):42-48.

15. Lin X, Heitman J. The biology of the Cryptococcus neoformans species complex. Annu Rev Microbiol. 2006;60:69-105.

16. Park BJ, Wannemuehler KA, Marston BJ, Govender N, Pappas PG, Chiller TM. Estimation of the current global burden of cryptococcal meningitis among persons living with HIV/AIDS. AIDS. 2009;23(4): 525-530.

17. Lin SJ, Schranz J, Teutsch SM. Aspergillosis case-fatality rate: systematic review of the literature. Clin Infect Dis. 2001;32(3):358-366.

18. Xie JL, Polvi EJ, Shekhar-Guturja T, Cowen LE. Elucidating drug resistance in human fungal pathogens. Future Microbiol. 2014;9(4): 523-542.

19. Chen SC, Playford EG, Sorrell TC. Antifungal therapy in invasive fungal infections. Curr Opin Pharmacol. 2010;10(5):522-530.

20. Chandrasekar P. Management of invasive fungal infections: a role for polyenes. J Antimicrob Chemother. 2011;66(3):457-465.

21. Petrikkos G, Skiada A. Recent advances in antifungal chemotherapy. Int J Antimicrob Agents. 2007;30(2):108-117.

22. Allen D, Wilson D, Drew R, Perfect J. Azole antifungals: 35 years of invasive fungal infection management. Expert Rev Anti Infect Ther. 2015;13(6):787-798.

23. Ascioglu S, Chan KA. Utilization and comparative effectiveness of caspofungin and voriconazole early after market approval in the U.S. PLoS One. 2014;9(1):e83658.

24. Chandwani S, Wentworth C, Burke TA, Patterson TF. Utilization and dosage pattern of echinocandins for treatment of fungal infections in US hospital practice. Curr Med Res Opin. 2009;25(2):385-393.

25. McCormack P. Isavuconazonium: first global approval. Drugs. 2015; 75(7):817-822.

26. Weissig V, Pettinger TK, Murdock N. Nanopharmaceuticals (part 1): products on the market. Int J Nanomedicine. 2014;9:4357-4373.

27. Calixto G, Bernegossi J, Fonseca-Santos B, Chorilli M. Nanotechnologybased drug delivery systems for treatment of oral cancer: a review. Int J Nanomedicine. 2014;9:3719-3735.

28. Couvreur P. Nanoparticles in drug delivery: past, present and future. Adv Drug Deliv Rev. 2013;65(1):21-23

29. Wilczewska AZ, Niemirowicz K, Markiewicz KH, Car H. Nanoparticles as drug delivery systems. Pharmacol Rep. 2012;64:1020-1037.

30. Liakos I, Grumezescu AM, Holban AM. Magnetite nanostructures as novel strategies for anti-infectious therapy. Molecules. 2014;19(8): $12710-12726$
31. Baumgartner J, Bertinetti L, Widdrat M, Hirt AM, Faivre D. Formation of magnetite nanoparticles at low temperature: from superparamagnetic to stable single domain particles. PLoS One. 2013;8(3):e57070.

32. Astruc D. Electron-transfer processes in dendrimers and their implication in biology, catalysis, sensing and nanotechnology. Nat Chem. 2012; 4(4):255-267.

33. Carrillo-Muñoz AJ, Quindós G, Tur C, et al. In-vitro antifungal activity of liposomal nystatin in comparison with nystatin, amphotericin B cholesteryl sulphate, liposomal amphotericin B, amphotericin B lipid complex, amphotericin B desoxycholate, fluconazole and itraconazole. J Antimicrob Chemother. 1999;44(3):397-401.

34. Quindós G, Carrillo-Muñoz AJ, Ruesga MT, et al. In vitro activity of a new liposomal nystatin formulation against opportunistic fungal pathogens. Eur J Clin Microbiol Infect Dis. 2000;19(8):645-648.

35. Hamill RJ. Amphotericin B formulations: a comparative review of efficacy and toxicity. Drugs. 2013;73(9):919-934.

36. Cornely OA. Aspergillus to zygomycetes: causes, risk factors, prevention, and treatment of invasive fungal infections. Infection. 2008;36(4): 296-313.

37. Laniado-Laborín R, Cabrales-Vargas MN. Amphotericin B: side effects and toxicity. Rev Iberoam Micol. 2009;26(4):223-227.

38. Moen MD, Lyseng-Williamson KA, Scott LJ. Liposomal amphotericin $B$ : a review of its use as empirical therapy in febrile neutropenia and in the treatment of invasive fungal infections. Drugs. 2009;69(3):361-392.

39. Gómez J, García-Vázquez E, Hernández A, Espinosa C, Ruiz J. Nosocomial candidemia: new challenges of an emergent problem. Rev Esp Quimioter. 2010;23(4):158-168.

40. Working PK. Amphotericin B colloidal dispersion. Pre-clinical review. Chemotherapy. 1999;45(suppl 1):15-26.

41. Groll AH, Mickiene D, Piscitelli SC, Walsh TJ. Distribution of lipid formulations of amphotericin B into bone marrow and fat tissue in rabbits. Antimicrob Agents Chemother. 2000;44(2):408-410.

42. Fielding RM, Singer AW, Wang LH, Babbar S, Guo LS. Relationship of pharmacokinetics and drug distribution in tissue to increased safety of amphotericin B colloidal dispersion in dogs. Antimicrob Agents Chemother. 1992;36(2):299-307.

43. Patel R. Amphotericin B colloidal dispersion. Expert Opin Pharmacother. 2000;1(3):475-488.

44. Arney KL, Tiernan R, Judson MA. Primary pulmonary involvement of Fusarium solani in a lung transplant recipient. Chest. 1997;112(4): 1128-1130.

45. Quindós G, Carrillo-Muñoz AJ, Arévalo MP, et al. In vitro susceptibility of Candida dubliniensis to current and new antifungal agents. Chemotherapy. 2000;46(6):395-401.

46. Sivak O, Bartlett K, Risovic V, et al. Assessing the antifungal activity and toxicity profile of amphotericin B lipid complex (ABLC; Abelcet) in combination with Caspofungin in experimental systemic aspergillosis. J Pharm Sci. 2004;93(6):1382-1389.

47. Polacheck I, Nagler A, Okon E, Drakos P, Plaskowitz J, Kwon-Chung KJ. Aspergillus quadrilineatus, a new causative agent of fungal sinusitis. J Clin Microbiol. 1992;30(12):3290-3293.

48. Diamond DM, Bauer M, Daniel BE, et al. Amphotericin B colloidal dispersion combined with flucytosine with or without fluconazole for treatment of murine cryptococcal meningitis. Antimicrob Agents Chemother. 1998;42(3):528-533.

49. Vidovic A, Arsic-Arsenijevic V, Tomin D, et al. Proven invasive pulmonary mucormycosis successfully treated with amphotericin B and surgery in patient with acute myeloblastic leukemia: a case report. J Med Case Rep. 2013;7:263.

50. Dietze R, Fowler VG, Steiner TS, Pecanha PM, Corey GR. Failure of amphotericin B colloidal dispersion in the treatment of paracoccidioidomycosis. Am J Trop Med Hyg. 1999;60(5):837-839.

51. Hanson LH, Stevens DA. Comparison of antifungal activity of amphotericin B deoxycholate suspension with that of amphotericin B cholesteryl sulfate colloidal dispersion. Antimicrob Agents Chemother. 1992;36(2):486-488. 
52. Timmers GJ, Zweegman S, Simoons-Smit AM, van Loenen AC, Touw D, Huijgens PC. Amphotericin B colloidal dispersion (Amphocil) vs fluconazole for the prevention of fungal infections in neutropenic patients: data of a prematurely stopped clinical trial. Bone Marrow Transplant. 2000;25(8):879-884.

53. Vogelsinger H, Weiler S, Djanani A, et al. Amphotericin B tissue distribution in autopsy material after treatment with liposomal amphotericin $\mathrm{B}$ and amphotericin B colloidal dispersion. $J$ Antimicrob Chemother. 2006;57(6):1153-1160.

54. Ruijgrok EJ, Fens MHA, Bakker-Woudenberg IAJM, van Etten EWM, Vulto AG. Nebulization of four commercially available amphotericin B formulations in persistently granulocytopenic rats with invasive pulmonary aspergillosis: evidence for long-term biological activity. J Pharm Pharmacol. 2005;57(10):1289-1295.

55. Husain $\mathrm{S}$, Capitano B, Corcoran $\mathrm{T}$, et al. Intrapulmonary disposition of amphotericin B after aerosolized delivery of amphotericin B lipid complex (Abelcet; ABLC) in lung transplant recipients. Transplantation. 2010;90(11):1215-1219.

56. Yang W, Tam J, Miller DA, et al. High bioavailability from nebulized itraconazole nanoparticle dispersions with biocompatible stabilizers. Int J Pharm. 2008;361(1-2):177-188.

57. Hostetler JS, Clemons KV, Hanson LH, Stevens DA. Efficacy and safety of amphotericin B colloidal dispersion compared with those of amphotericin B deoxycholate suspension for treatment of disseminated murine cryptococcosis. Antimicrob Agents Chemother. 1992; 36(12):2656-2660.

58. Tkatch LS, Kusne S, Eibling D. Successful treatment of zygomycosis of the paranasal sinuses with surgical debridement and amphotericin B colloidal dispersion. Am J Otolaryngol. 1993;14(4):249-253.

59. Vukmir RB, Kusne S, Linden P, et al. Successful therapy for cerebral phaeohyphomycosis due to Dactylaria gallopava in a liver transplant recipient. Clin Infect Dis. 1994;19(4):714-719.

60. Herbrecht R, Letscher-Bru V, Bowden RA, et al. Treatment of 21 cases of invasive mucormycosis with amphotericin B colloidal dispersion. Eur J Clin Microbiol Infect Dis. 2001;20(7):460-466.

61. Noskin GA, Pietrelli L, Coffey G, Gurwith M, Liang LJ. Amphotericin B colloidal dispersion for treatment of candidemia in immunocompromised patients. Clin Infect Dis. 1998;26(2):461-467.

62. Moses AE, Rahav G, Barenholz Y, et al. Rhinocerebral mucormycosis treated with amphotericin B colloidal dispersion in three patients. Clin Infect Dis. 1998;26(6):1430-1433.

63. Hunstad DA, Cohen AH, St Geme JW. Successful eradication of mucormycosis occurring in a pulmonary allograft. J Heart Lung Transplant. 1999;18(8):801-804.

64. Bowden R, Chandrasekar P, White MH, et al. A double-blind, randomized, controlled trial of amphotericin B colloidal dispersion versus amphotericin B for treatment of invasive aspergillosis in immunocompromised patients. Clin Infect Dis. 2002;35(4):359-366.

65. Capilla J, Clemons KV, Sobel RA, Stevens DA. Efficacy of amphotericin B lipid complex in a rabbit model of coccidioidal meningitis. $J$ Antimicrob Chemother. 2007;60(3):673-676.

66. Weiler S, Uberlacher E, Schofmann J, et al. Pharmacokinetics of amphotericin B colloidal dispersion in critically ill patients with cholestatic liver disease. Antimicrob Agents Chemother. 2012;56(10):5414-5418

67. Sun HY, Cacciarelli TV, Singh N. Micafungin versus amphotericin B lipid complex for the prevention of invasive fungal infections in high-risk liver transplant recipients. Transplantation. 2013;96(6): 573-578.

68. Madni A, Sarfraz M, Rehman M, Ahmad M, Akhtar N, Ahmad S. Liposomal drug delivery: a versatile platform for challenging clinical applications. J Pharm Pharm Sci. 2014;17(3):401-426.

69. Dai Y, Zhou R, Liu L, Lu Y, Qi J, Wu W. Liposomes containing bile salts as novel ocular delivery systems for tacrolimus (FK506): in vitro characterization and improved corneal permeation. Int J Nanomedicine. 2013;8:1921-1933.

70. Corcoran TE, Venkataramanan R, Mihelc KM, et al. Aerosol deposition of lipid complex amphotericin-B (Abelcet) in lung transplant recipients. Am J Transplant. 2006;6(11):2765-2773.
71. Hatakeyama H, Akita H, Harashima H. The polyethyleneglycol dilemma: advantage and disadvantage of PEGylation of liposomes for systemic genes and nucleic acids delivery to tumors. Biol Pharm Bull. 2013; 36(6):892-899.

72. Ahmad I, Allen TM. Antibody-mediated specific binding and cytotoxicity of liposome-entrapped doxorubicin to lung cancer cells in vitro. Cancer Res. 1992;52(17):4817-4820.

73. Joo KI, Xiao L, Liu S, et al. Crosslinked multilamellar liposomes for controlled delivery of anticancer drugs. Biomaterials. 2013;34(12): 3098-3109.

74. Ibrahim AS, Avanessian V, Spellberg B, Edwards JE. Liposomal amphotericin B, and not amphotericin B deoxycholate, improves survival of diabetic mice infected with Rhizopus oryzae. Antimicrob Agents Chemother. 2003;47(10):3343-3344.

75. Ortoneda M, Capilla J, Pastor FJ, Pujol I, Guarro J. Efficacy of liposomal amphotericin B in treatment of systemic murine fusariosis. Antimicrob Agents Chemother. 2002;46(7):2273-2275.

76. Olson JA, Adler-Moore JP, Jensen GM, Schwartz J, Dignani MC, Proffitt RT. Comparison of the physicochemical, antifungal, and toxic properties of two liposomal amphotericin B products. Antimicrob Agents Chemother. 2008;52(1):259-268.

77. Sloan DJ, Parris V. Cryptococcal meningitis: epidemiology and therapeutic options. Clin Epidemiol. 2014;6:169-182.

78. Clemons KV, Sobel RA, Williams PL, Pappagianis D, Stevens DA. Efficacy of intravenous liposomal amphotericin B (AmBisome) against coccidioidal meningitis in rabbits. Antimicrob Agents Chemother. 2002;46(8): 2420-2426.

79. Clemons KV, Capilla J, Sobel RA, Martinez M, Tong AJ, Stevens DA. Comparative efficacies of lipid-complexed amphotericin B and liposomal amphotericin B against coccidioidal meningitis in rabbits. Antimicrob Agents Chemother. 2009;53(5):1858-1862.

80. Clemons KV, Stevens DA. Therapeutic efficacy of a liposomal formulation of amphotericin B (AmBisome) against murine blastomycosis. J Antimicrob Chemother. 1993;32(3):465-472.

81. Olson JA, Adler-Moore JP, Schwartz J, Jensen GM, Proffitt RT. Comparative efficacies, toxicities, and tissue concentrations of amphotericin B lipid formulations in a murine pulmonary aspergillosis model. Antimicrob Agents Chemother. 2006;50(6):2122-2131.

82. Al Nakeeb Z, Petraitis V, Goodwin J, Petraitiene R, Walsh TJ, Hope WW. Pharmacodynamics of amphotericin B deoxycholate, amphotericin B lipid complex and liposomal amphotericin B against Aspergillus fumigatus. Antimicrob Agents Chemother. 2015;59(5): $2735-2745$

83. Ariano RE, Mitchelmore BR, Lagacé-Wiens PR, Zelenitsky SA. Successful treatment of pulmonary blastomycosis with continuously infused amphotericin B deoxycholate after failure with liposomal amphotericin B. Ann Pharmacother. 2013;47(6):e26.

84. Akyol Erikci A, Ozyurt M, Terekeci H, Ozturk A, Karabudak O, Oncu K. Oesophageal aspergillosis in a case of acute lymphoblastic leukaemia successfully treated with caspofungin alone due to liposomal amphotericin B induced severe hepatotoxicity. Mycoses. 2009;52(1): 84-86.

85. Sato MR, da Silva PB, de Souza RA, dos Santos KC, Chorilli M. Recent advances in nanoparticle carriers for coordination complexes. Curr Top Med Chem. 2015;15(4):287-297.

86. Liu JS, Chang YY, Chen WH, Chen SS. Amphotericin B-induced leukoencephalopathy in a patient with cryptococcal meningitis. J Formos Med Assoc. 1995;94(7):432-434.

87. Michot JM, Gubavu C, Fourn E, et al. Very prolonged liposomal amphotericin B use leading to a lysosomal storage disease. Int $J$ Antimicrob Agents. 2014;43(6):566-569.

88. Hospenthal DR, Rogers AL, Mills GL. Development of amphotericin B liposomes bearing antibody specific to Candida albicans. Mycopathologia. 1988;101(1):37-45.

89. Gilbert BE, Wyde PR, Wilson SZ. Aerosolized liposomal amphotericin B for treatment of pulmonary and systemic Cryptococcus neoformans infections in mice. Antimicrob Agents Chemother. 1992;36(7): $1466-1471$. 
90. Mihara T, Kakeya H, Izumikawa K, et al. Efficacy of aerosolized liposomal amphotericin B against murine invasive pulmonary mucormycosis. J Infect Chemother. 2014;20(2):104-108.

91. Alonso-Vargas R, González-Alvarez L, Ruesga MT, et al. In vitro activity of a liposomal nystatin formulation (Nyotran) against Cryptococcus neoformans. Rev Iberoam Micol. 2000;17(3):90-92.

92. Oakley KL, Moore CB, Denning DW. Comparison of in vitro activity of liposomal nystatin against Aspergillus species with those of nystatin, amphotericin $\mathrm{B}(\mathrm{AB})$ deoxycholate, $\mathrm{AB}$ colloidal dispersion, liposomal AB, AB lipid complex, and itraconazole. Antimicrob Agents Chemother. 1999;43(5):1264-1266.

93. Lopez-Berestein G, Bodey GP, Frankel LS, Mehta K. Treatment of hepatosplenic candidiasis with liposomal-amphotericin B. JClin Oncol. 1987; 5(2):310-317.

94. Schinabeck MK, Long LA, Hossain MA, et al. Rabbit model of Candida albicans biofilm infection: liposomal amphotericin B antifungal lock therapy. Antimicrob Agents Chemother. 2004;48(5):1727-1732.

95. Seidler M, Salvenmoser S, Müller FM. Liposomal amphotericin B eradicates Candida albicans biofilm in a continuous catheter flow model. FEMS Yeast Res. 2010;10(4):492-495.

96. Ramage G, Jose A, Sherry L, Lappin DF, Jones B, Williams C. Liposomal amphotericin B displays rapid dose-dependent activity against Candida albicans biofilms. Antimicrob Agents Chemother. 2013;57(5): 2369-2371.

97. Drew R. Potential role of aerosolized amphotericin B formulations in the prevention and adjunctive treatment of invasive fungal infections. Int J Antimicrob Agents. 2006;27(suppl 1):36-44.

98. Roth C, Gebhart J, Just-Nubling G, von Eisenhart-Rothe B, BeinhauerReeb I. Characterization of amphotericin B aerosols for inhalation treatment of pulmonary aspergillosis. Infection. 1996;24(5):354-360.

99. Gilbert BE, Wyde PR, Lopez-Berestein G, Wilson SZ. Aerosolized amphotericin B-liposomes for treatment of systemic Candida infections in mice. Antimicrob Agents Chemother. 1994;38(2):356-359.

100. Lopez-Berestein G, Mehta R, Hopfer R, Mehta K, Hersh EM, Juliano R. Effects of sterols on the therapeutic efficacy of liposomal amphotericin B in murine candidiasis. Cancer Drug Deliv. 1983;1(1):37-42.

101. Lopez-Berestein G, Fainstein V, Hopfer R, et al. Liposomal amphotericin $\mathrm{B}$ for the treatment of systemic fungal infections in patients with cancer: a preliminary study. J Infect Dis. 1985;151(4):704-710.

102. Weber RS, Lopez-Berestein G. Treatment of invasive Aspergillus sinusitis with liposomal-amphotericin B. Laryngoscope. 1987;97(8 pt 1): 937-941.

103. Pontani DR, Sun D, Brown JW, et al. Inhibition of HIV replication by liposomal encapsulated amphotericin B. Antiviral Res. 1989;11(3): 119-125.

104. Katz NM, Pierce PF, Anzeck RA, et al. Liposomal amphotericin B for treatment of pulmonary aspergillosis in a heart transplant patient. J Heart Transplant. 1990;9(1):14-17.

105. Tollemar J, Duraj F, Ericzon BG. Liposomal amphotericin B treatment in a 9-month-old liver recipient. Mycoses. 1990;33(5):251-252.

106. Antunes AM, Teixeira C, Corvo ML, Perdigoto R, Barroso E, Marcelino P. Prophylactic use of liposomal amphotericin B in preventing fungal infections early after liver transplantation: a retrospective, single-center study. Transplant Proc. 2014;46(10):3554-3559.

107. Selleslag D. A case of fusariosis in an immunocompromised patient successfully treated with liposomal amphotericin B. Acta Biomed. 2006; 77(suppl 2):32-35.

108. Fisher EW, Toma A, Fisher PH, Cheesman AD. Rhinocerebral mucormycosis: use of liposomal amphotericin B. J Laryngol Otol. 1991; 105(7):575-577.

109. Lim KK, Potts MJ, Warnock DW, Ibrahim NB, Brown EM, BurnsCox CJ. Another case report of rhinocerebral mucormycosis treated with liposomal amphotericin B and surgery. Clin Infect Dis. 1994;18(4): 653-654.

110. Ogawa T, Takezawa K, Tojima I, et al. Successful treatment of rhino-orbital mucormycosis by a new combination therapy with liposomal amphotericin B and micafungin. Auris Nasus Larynx. 2012; 39(2):224-228
111. Munckhof W, Jones R, Tosolini FA, Marzec A, Angus P, Grayson ML. Cure of Rhizopus sinusitis in a liver transplant recipient with liposomal amphotericin B. Clin Infect Dis. 1993;16(1):183.

112. Coker RJ, Viviani M, Gazzard BG, et al. Treatment of cryptococcosis with liposomal amphotericin B (AmBisome) in 23 patients with AIDS. AIDS. 1993;7(6):829-835.

113. Karatza AA, Dimitriou G, Marangos M, et al. Successful resolution of cardiac mycetomas by combined liposomal Amphotericin B with Fluconazole treatment in premature neonates. Eur J Pediatr. 2008; 167(9):1021-1023.

114. Tunger O, Bayram H, Degerli K, Dinc G, Cetin BC. Comparison of the efficacy of combination and monotherapy with caspofungin and liposomal amphotericin B against invasive candidiasis. Saudi Med J. 2008; 29(5):728-733.

115. Buckler BS, Sams RN, Goei VL, et al. Treatment of central venous catheter fungal infection using liposomal amphotericin-B lock therapy. Pediatr Infect Dis J. 2008;27(8):762-764.

116. Kashimoto S, Takemoto K, Yamamoto Y, Kanazawa K. In vivo activity of liposomal amphotericin B against Exophiala dermatitidis in a murine lethal infection model. Jpn J Antibiot. 2010;63(3):265-272.

117. Ruíz-Cendoya M, Pastor FJ, Capilla J, Guarro J. Treatment of murine Fusarium verticillioides infection with liposomal amphotericin B plus terbinafine. Int J Antimicrob Agents. 2011;37(1):58-61.

118. Inoue $\mathrm{A}$, Harada $\mathrm{H}$, Iwata $\mathrm{S}$, et al. Intraventricular cryptococcoma successfully treated with liposomal amphotericin B and voriconazole: a case report. No Shinkei Geka. 2012;40(9):777-784.

119. Sharma LC, Falodia J, Kalla K, et al. Esophageal histoplasmosis in a renal allograft recipient. Saudi J Kidney Dis Transpl. 2013;24(4): 764-767.

120. Brazzola P, Rossi MR. High weekly doses of liposomal amphotericin $\mathrm{B}$ as secondary prophylaxis after cerebral aspergillosis in a paediatric patient. Med Mycol Case Rep. 2013;3(1):1-3.

121. Ville S, Talarmin JP, Gaultier-Lintia A, et al. Disseminated mucormycosis with cerebral involvement owing to rhizopus microsporus in a kidney recipient treated with combined liposomal amphotericin $\mathrm{b}$ and posaconazole therapy. Exp Clin Transpl. 2016;14(1):96-99.

122. Kleinotiene G, Posiunas G, Raistenskis J, et al. Liposomal amphotericin B and surgery as successful therapy for pulmonary Lichtheimia corymbifera zygomycosis in a pediatric patient with acute promyelocytic leukemia on antifungal prophylaxis with posaconazole. Med Oncol. 2013;30(1):433.

123. Hand EO, Ramanathan MR. Safety and tolerability of high-dose weekly liposomal amphotericin B antifungal prophylaxis. Pediatr Infect Dis J. 2014;33(8):835-836.

124. Storm L, Lausch KR, Arendrup MC, Mortensen KL, Petersen E. Vertebral infection with Candida albicans failing caspofungin and fluconazole combination therapy but successfully treated with high dose liposomal amphotericin B and flucytosine. Med Mycol Case Rep. 2014;6:6-9.

125. Rousseau N, Picot SB, Bienvenu AL. Erythropoietin combined with liposomal amphotericin B improves outcome during disseminated aspergillosis in mice. Front Immunol. 2014;5:502.

126. Fujita M, Yanagisawa J, Hiratsuka M, et al. A case report of pulmonary aspergillosis in lung transplant recipient successfully treated with inhalation administration of liposomal amphotericin B. Jpn J Antibiot. 2013;66(1):37-43.

127. Godet C, Goudet V, Laurent F, et al. Nebulised liposomal amphotericin B for Aspergillus lung diseases: case series and literature review. Mycoses. 2015;58(3):173-180.

128. Hanada S, Uruga H, Takaya H, et al. Nebulized liposomal amphotericin B for treating Aspergillus empyema with bronchopleural fistula. Am J Respir Crit Care Med. 2014;189(5):607-608.

129. Souza AC, Nascimento AL, de Vasconcelos NM, et al. Activity and in vivo tracking of amphotericin B loaded PLGA nanoparticles. Eur J Med Chem. 2015;95:267-276.

130. Mukherjee S, Ray S, Thakur RS. Design and evaluation of Itraconazole loaded solid lipid nanoparticulate system for improving the antifungal therapy. PakJ Pharm Sci. 2009;22(2):131-138. 
131. Pardeshi C, Rajput P, Belgamwar V, et al. Solid lipid based nanocarriers: an overview. Acta Pharm. 2012;62(4):433-472.

132. Nayak AP, Tiyaboonchai W, Patankar S, Madhusudhan B, Souto EB. Curcuminoids-loaded lipid nanoparticles: novel approach towards malaria treatment. Colloids Surf B Biointerfaces. 2010;81(1): 263-273.

133. Muchow M, Maincent $P$, Muller RH. Lipid nanoparticles with a solid matrix (SLN, NLC, LDC) for oral drug delivery. Drug Dev Ind Pharm. 2008;34(12):1394-1405.

134. Abdel-Mottaleb MMA, Neumann D, Lamprecht A. Lipid nanocapsules for dermal application: a comparative study of lipid-based versus polymer-based nanocarriers. Eur J Pharm Biopharm. 2011;79(1): $36-42$.

135. Attama AA, Schicke BC, Paepenmüller T, Müller-Goymann CC. Solid lipid nanodispersions containing mixed lipid core and a polar heterolipid: characterization. Eur J Pharm Biopharm. 2007;67(1):48-57.

136. Liu J, Gong T, Fu H, et al. Solid lipid nanoparticles for pulmonary delivery of insulin. Int J Pharm. 2008;356(1-2):333-344.

137. Sznitowska M, Gajewska M, Janicki S, Radwanska A, Lukowski G. Bioavailability of diazepam from aqueous-organic solution, submicron emulsion and solid lipid nanoparticles after rectal administration in rabbits. Eur J Pharm Biopharm. 2001;52(2):159-163.

138. Müller RH, Radtke M, Wissing SA. Solid lipid nanoparticles (SLN) and nanostructured lipid carriers (NLC) in cosmetic and dermatological preparations. Adv Drug Deliv Rev. 2002;54(suppl 1):S131-S155.

139. Zhang L, Chan JM, Gu FX, et al. Self-assembled lipid-polymer hybrid nanoparticles: a robust drug delivery platform. ACS Nano. 2008;2(8): $1696-1702$.

140. Salvador-Morales C, Zhang L, Langer R, Farokhzad OC. Immunocompatibility properties of lipid-polymer hybrid nanoparticles with heterogeneous surface functional groups. Biomaterials. 2009;30(12): 2231-2240.

141. Müller RH, Runge SA, Ravelli V, Thünemann AF, Mehnert W, Souto EB. Cyclosporine-loaded solid lipid nanoparticles $\left(\mathrm{SLN}^{\circledR}\right)$ : drug-lipid physicochemical interactions and characterization of drug incorporation. Eur J Pharm Biopharm. 2008;68(3):535-544.

142. Tan SW, Billa N, Roberts CR, Burley JC. Surfactant effects on the physical characteristics of Amphotericin B-containing nanostructured lipid carriers. Colloids Surf A Physicochem Eng Asp. 2010;372(1-3):73-79.

143. Kovacevic A, Savic S, Vuleta G, Müller RH, Keck CM. Polyhydroxy surfactants for the formulation of lipid nanoparticles (SLN and NLC): effects on size, physical stability and particle matrix structure. Int $J$ Pharm. 2011;406(1-2):163-172.

144. Mathpal D, Garg T, Rath G, Goyal AK. Development and characterization of spray dried microparticles for pulmonary delivery of antifungal drug. Curr Drug Deliv. 2015;12(4):464-471.

145. Mohanty B, Majumdar DK, Mishra SK, Panda AK, Patnaik S. Development and characterization of itraconazole-loaded solid lipid nanoparticles for ocular delivery. Pharm Dev Technol. 2015;20(4):458-464.

146. Pardeike J, Weber S, Haber T, et al. Development of an Itraconazoleloaded nanostructured lipid carrier (NLC) formulation for pulmonary application. Int J Pharm. 2011;419(1-2):329-338.

147. Lim WM, Rajinikanth PS, Mallikarjun C, Kang YB. Formulation and delivery of itraconazole to the brain using a nanolipid carrier system. Int J Nanomedicine. 2014;9:2117-2126.

148. Sanap GS, Mohanta GP. Design and evaluation of miconazole nitrate loaded nanostructured lipid carriers (NLC) for improving the antifungal therapy. J Appl Pharm Sci. 2013;3(1):46-54.

149. Keshri L, Pathak K. Development of thermodynamically stable nanostructured lipid carrier system using central composite design for zero order permeation of Econazole nitrate through epidermis. Pharm Dev Technol. 2012;18(3):1-11.

150. Song SH, Lee KM, Kang JB, Lee SG, Kang MJ, Choi YW. Improved skin delivery of voriconazole with a nanostructured lipid carrierbased hydrogel formulation. Chem Pharm Bull (Tokyo). 2014;62(8): 793-798.

151. Lemke A, Kiderlen AF, Kayser O. Amphotericin B. Appl Microbiol Biotechnol. 2005;68(2):151-162.
152. Jain S, Jain S, Khare P, Gulbake A, Bansal D, Jain SK. Design and development of solid lipid nanoparticles for topical delivery of an anti-fungal agent. Drug Deliv. 2010;17(6):443-451.

153. Gupta M, Vyas SP. Development, characterization and in vivo assessment of effective lipidic nanoparticles for dermal delivery of fluconazole against cutaneous candidiasis. Chem Phys Lipids. 2012;165(4): 454-461.

154. Ravani L, Esposito E, Bories C, et al. Clotrimazole-loaded nanostructured lipid carrier hydrogels: thermal analysis and in vitro studies. Int J Pharm. 2013;454(2):695-702.

155. Mendes AI, Silva AC, Catita JAM, Cerqueira F, Gabriel C, Lopes CM. Miconazole-loaded nanostructured lipid carriers (NLC) for local delivery to the oral mucosa: improving antifungal activity. Colloids Surf B Biointerfaces. 2013;111:755-763.

156. Gupta M, Tiwari S, Vyas SP. Influence of various lipid core on characteristics of SLNs designed for topical delivery of fluconazole against cutaneous candidiasis. Pharm Dev Technol. 2013;18(3):550-559.

157. Vaghasiya H, Kumar A, Sawant K. Development of solid lipid nanoparticles based controlled release system for topical delivery of terbinafine hydrochloride. Eur J Pharm Sci. 2013;49(2):311-322.

158. Cassano R, Ferrarelli T, Mauro MV, Cavalcanti P, Picci N, Trombino S. Preparation, characterization and in vitro activities evaluation of solid lipid nanoparticles based on PEG-40 stearate for antifungal drugs vaginal delivery. Drug Deliv. 2016;23(3):1047-1056.

159. Melo S, Cunha S, Fialho SL. Formas farmacêuticas poliméricas para a administração de peptídeos e proteínas terapêuticos [Polymeric delivery systems for the administration of therapeutic peptides and proteins]. Rev Ciênc Farm Básica Apl. 2012;33(4):469-477. Portuguese.

160. Pridgen EM, Alexis F, Farokhzad OC. Polymeric nanoparticle technologies for oral drug delivery. Clin Gastroenterol Hepatol. 2014;12(10): 1605-1610.

161. Valencia PM, Pridgen EM, Rhee M, Langer R, Farokhzad OC, Karnik R. Microfluidic platform for combinatorial synthesis and optimization of targeted nanoparticles for cancer therapy. ACS Nano. 2013;7(12):10671-10680.

162. Yu MK, Park J, Jon S. Targeting strategies for multifunctional nanoparticles in cancer imaging and therapy. Theranostics. 2012;2(1): 3-44.

163. des Rieux A, Fievez V, Garinot M, Schneider YJ, Préat V. Nanoparticles as potential oral delivery systems of proteins and vaccines: a mechanistic approach. J Controll Release. 2006;116(1):1-27.

164. Bilensoy E, Sarisozen C, Esendağli G, et al. Intravesical cationic nanoparticles of chitosan and polycaprolactone for the delivery of Mitomycin C to bladder tumors. Int J Pharm. 2009;371(1-2): 170-176.

165. Bai J, Li Y, Du J, et al. One-pot synthesis of polyacrylamide-gold nanocomposite. Mater Chem Phys. 2007;106(2-3):412-415.

166. Turos E, Shim JY, Wang Y, et al. Antibiotic-conjugated polyacrylate nanoparticles: new opportunities for development of anti-MRSA agents. Bioorg Med Chem Lett. 2007;17(1):53-56.

167. Mao HQ, Roy K, Troung-Le VL, et al. Chitosan-DNA nanoparticles as gene carriers: synthesis, characterization and transfection efficiency. J Control Release. 2001;70(3):399-421.

168. Rejinold NS, Muthunarayanan M, Muthuchelian K, Chennazhi KP, Nair SV, Jayakumar R. Saponin-loaded chitosan nanoparticles and their cytotoxicity to cancer cell lines in vitro. Carbohydr Polym. 2011; 84(1):407-416.

169. Gonçalves JO, Duarte DAD, Plaa GL. Use of chitosan with different deacetylation degrees for the adsorption of food dyes in a binary system. Clean Soil Air Water. 2014;42(6):767-774.

170. Saraogi GK, Gupta P, Gupta UD, Jain NK, Agrawal GP. Gelatin nanocarriers as potential vectors for effective management of tuberculosis. Int J Pharm. 2010;385(1-2):143-149.

171. Luo G, Yu X, Jin C, et al. LyP-1-conjugated nanoparticles for targeting drug delivery to lymphatic metastatic tumors. Int J Pharm. 2010; 385(1-2):150-156.

172. Mora-Huertas CE, Fessi H, Elaissari A. Polymer-based nanocapsules for drug delivery. Int J Pharm. 2010;385(1-2):113-142. 
173. Schaffazick SR, Guterres SS, De Lucca Freitas L, Pohlmann AR. Caracterização e estabilidade físico-química de sistemas poliméricos nanoparticulados para administração de fármacos. [Physicochemical characterization and stability of the polymeric nanoparticle systems for drug administration] Quim Nova. 2003;26(5):726-737. Portuguese.

174. Anselmo AC, Mitragotri S. A review of clinical translation of inorganic nanoparticles. AAPS J. 2015;17(5):1041-1054.

175. Pinto RJB, Almeida A, Fernandes SCM, et al. Antifungal activity of transparent nanocomposite thin films of pullulan and silver against Aspergillus niger. Colloids Surf B Biointerfaces. 2013;103:143-148.

176. Silva S, Pires P, Monteiro DR, et al. The effect of silver nanoparticles and nystatin on mixed biofilms of Candida glabrata and Candida albicans on acrylic. Med Mycol. 2013;51(2):178-184.

177. Monteiro DR, Negri M, Silva S, et al. Adhesion of Candida biofilm cells to human epithelial cells and polystyrene after treatment with silver nanoparticles. Colloids Surf B Biointerfaces. 2014;114:410-412.

178. Mehnert W, Mader K. Solid lipid nanoparticles - production, characterization and applications. Adv Drug Deliv Rev. 2001;47(2-3): 165-196.

179. Vakil R, Knilans K, Andes D, Kwon GS. Combination antifungal therapy involving amphotericin B, rapamycin and 5-fluorocytosine using PEG-phospholipid micelles. Pharm Res. 2008;25(9):2056-2064.

180. Wang CH, Wang WT, Hsiue GH. Development of polyion complex micelles for encapsulating and delivering amphotericin B. Biomaterials. 2009;30(19):3352-3358.

181. Amaral AC, Marques AF, Muñoz JE, et al. Poly(lactic acid-glycolic acid) nanoparticles markedly improve immunological protection provided by peptide $\mathrm{P} 10$ against murine paracoccidioidomycosis. $\mathrm{Br}$ J Pharmacol. 2010;159(5):1126-1132.

182. Xu N, Gu J, Zhu Y, Wen H, Ren Q, Chen J. Efficacy of intravenous amphotericin B-polybutylcyanoacrylate nanoparticles against cryptococcal meningitis in mice. Int $J$ Nanomedicine. 2011;6: 905-913.

183. Patel NR, Damann K, Leonardi C, Sabliov C. Size dependency of PLGA-nanoparticle uptake and antifungal activity against Aspergillus flavus. Nanomedicine (Lond). 2011;6(8):1381-1395.

184. Cunha-Azevedo EP, Silva JR, Martins OP, et al. In vitro antifungal activity and toxicity of itraconazole in DMSA-PLGA nanoparticles. J Nanosci Nanotechnol. 2011;11(3):2308-2314.

185. Roy Choudhury S, Ghosh M, Mandal A, et al. Surface-modified sulfur nanoparticles: an effective antifungal agent against Aspergillus niger and Fusarium oxysporum. Appl Microbiol Biotechnol. 2011;90(2): 733-743.

186. Shim YH, Kim YC, Lee HJ, et al. Amphotericin b aggregation inhibition with novel nanoparticles prepared with poly(E-caprolactone)/ poly(N,N-dimethylamino-2-ethyl methacrylate) diblock copolymer. J Microbiol Biotechnol. 2011;21(1):28-36.

187. Haghighi F, Mohammadi ShR, Mohammadi P, Eskandari M, Hosseinkhani S. The evaluation of Candida albicans biofilms formation on silicone catheter, PVC and glass coated with titanium dioxide nanoparticles by XTT method and ATPase assay. Bratisl Lek List. 2012;113(12):707-711

188. Shao K, Wu J, Chen Z, et al. A brain-vectored angiopep-2 based polymeric micelles for the treatment of intracranial fungal infection. Biomaterials. 2012;33(28):6898-6907.

189. Van De Ven H, Paulussen C, Feijens PB, et al. PLGA nanoparticles and nanosuspensions with amphotericin B: potent in vitro and in vivo alternatives to Fungizone and AmBisome. J Control Release. 2012; 161(3):795-803.

190. Mohammed N, Sanoj Rejinold N, Mangalathillam S, Biswas R, Nair SV, Jayakumar R. Fluconazole loaded chitin nanogels as a topical ocular drug delivery agent for corneal fungal infections. J Biomed Nanotechnol. 2013;9(9):1521-1531.

191. Mathew TV, Kuriakose S. Photochemical and antimicrobial properties of silver nanoparticle-encapsulated chitosan functionalized with photoactive groups. Mater Sci Eng C. 2013;33(7):4409-4415.
192. Santos SS, Lorenzoni A, Ferreira LM, et al. Clotrimazole-loaded Eudragit ${ }^{\circledR}$ RS100 nanocapsules: preparation, characterization and in vitro evaluation of antifungal activity against Candida species. Mater Sci Eng C Mater Biol Appl. 2013;33(3):1389-1394.

193. Basha M, Abd El-Alim SH, Shamma RN, Awad GE. Design and optimization of surfactant-based nanovesicles for ocular delivery of Clotrimazole. J Liposome Res. 2013;23(3):203-210.

194. Santos SS, Lorenzoni A, Pegoraro NS, et al. Formulation and in vitro evaluation of coconut oil-core cationic nanocapsules intended for vaginal delivery of clotrimazole. Colloids Surf B Biointerfaces. 2014; 116:270-276

195. Azevedo MM, Ramalho P, Silva AP, Teixeira-Santos R, Pina-Vaz C, Rodrigues AG. Polyethyleneimine and polyethyleneimine-based nanoparticles: novel bacterial and yeast biofilm inhibitors. $J$ Med Microbiol. 2014;63(pt 9):1167-1173.

196. Lazniewska J, Milowska K, Gabryelak T. Dendrimers-revolutionary drugs for infectious diseases. Wiley Interdiscip Rev Nanomed Nanobiotechnol. 2012;4(5):469-491.

197. Wu L, Ficker M, Christensen JB, Trohopoulos PN, Moghimi SM. Dendrimers in medicine: therapeutic concepts and pharmaceutical challenges. Bioconjug Chem. 2015;26(7):1198-1211.

198. D’Emanuele A, Attwood D. Dendrimer-drug interactions. Adv Drug Deliv Rev. 2005;57(15):2147-2162.

199. Menjoge AR, Kannan RM, Tomalia DA. Dendrimer-based drug and imaging conjugates: design considerations for nanomedical applications. Drug Discov Today. 2010;15(5-6):171-185.

200. Gajbhiye V, Vijayaraj Kumar P, Kumar Tekade R, Jain NK. Pharmaceutical and biomedical potential of pegylated dendrimers. Curr Pharm Design. 2007;13:415-429.

201. Ziemba B, Janaszewska A, Ciepluch $\mathrm{K}$, et al. In vivo toxicity of poly(propyleneimine) dendrimers. J Biomed Mater Res A. 2011;99(2): 261-268.

202. Kolhatkar RB, Kitchens KM, Swaan PW, Ghandehari H. Surface acetylation of polyamidoamine (PAMAM) dendrimers decreases cytotoxicity while maintaining membrane permeability. Bioconjug Chem. 2007;18(6):2054-2060.

203. Singh P, Gupta U, Asthana A, Jain NK. Folate and Folate-PEGPAMAM dendrimers: synthesis, characterization, and targeted anticancer drug delivery potential in tumor bearing mice. Bioconjug Chem. 2008;19(11):2239-2252.

204. Wängler C, Moldenhauer G, Eisenhut M, Haberkorn U, Mier W. Antibody-dendrimer conjugates: the number, not the size of the dendrimers, determines the immunoreactivity. Bioconjug Chem. 2008; 19(4):813-820.

205. Waite CL, Roth CM. PAMAM-RGD conjugates enhance siRNA delivery through a multicellular spheroid model of malignant glioma. Bioconjug Chem. 2009;20(10):1908-1916.

206. Lopez AI, Reins RY, McDermott AM, Trautner BW, Cai C. Antibacterial activity and cytotoxicity of PEGylated poly(amidoamine) dendrimers. Mol Biosyst. 2009;5(10):1148-1156.

207. Winnicka K, Sosnowska K, Wieczorek P, Sacha PT, Tryniszewska E. Poly(amidoamine) dendrimers increase antifungal activity of Clotrimazole. Biol Pharm Bull. 2011;34(7):1129-1133.

208. Janiszewska J, Sowińska M, Rajnisz A, et al. Novel dendrimeric lipopeptides with antifungal activity. Bioorg Med Chem Lett. 2012;22(3): 1388-1393.

209. Staniszewska M, Bondaryk M, Zielinska P, Urbańczyk-Lipkowska Z. The in vitro effects of new D186 dendrimer on virulence factors of Candida albicans. J Antibiot (Tokyo). 2014;67(6):425-432.

210. Benincasa M, Pacor S, Wu W, Prato M, Bianco A, Gennaro R. Antifungal activity of amphotericin $\mathrm{B}$ conjugated to carbon nanotubes. ACS Nano. 2011;5(1):199-208.

211. Olivi M, Zanni E, De Bellis G, et al. Inhibition of microbial growth by carbon nanotube networks. Nanoscale. 2013;5(19):9023-9029.

212. Sawangphruk M, Srimuk P, Chiochan P, Sangsri T, Siwayaprahm P. Synthesis and antifungal activity of reduced graphene oxide nanosheets. Carbon N Y. 2012;50(14):5156-5161. 
213. Cui J, Yang Y, Zheng M, et al. Facile fabrication of graphene oxide loaded with silver nanoparticles as antifungal materials. Mater Res Express. 2014;1(4):45007.

214. Hussein-Al-Ali SH, El Zowalaty ME, Hussein MZ, Geilich BM, Webster TJ. Synthesis, characterization, and antimicrobial activity of an ampicillin-conjugated magnetic nanoantibiotic for medical applications. Int J Nanomedicine. 2014;9(1):3801-3814.

215. Niemirowicz K, Swiecicka I, Wilczewska AZ, et al. Growth arrest and rapid capture of select pathogens following magnetic nanoparticle treatment. Colloids Surf B Biointerfaces. 2015;131:29-38.

216. Roemer T, Krysan DJ. Antifungal drug development: challenges, unmet clinical needs, and new approaches. Cold Spring Harb Perspect Med. 2014;4(5):pii a019703.
217. Oyafuso MH, Carvalho FC, Chiavacci LA, Gremião MPD, Chorilli M. Design and characterization of silicone and surfactant based systems for topical drug delivery. J Nanosci Nanotechnol. 2015;15(1):817-826.

218. Liu X, Chen X, Li Y, Wang X, Peng X, Zhu W. Preparation of superparamagnetic Fe 3O4@alginate/chitosan nanospheres for candida rugosa lipase immobilization and utilization of layer-by-layer assembly to enhance the stability of immobilized lipase. ACS Appl Mater Interfaces. 2012;4(10):5169-5178.

\section{Publish your work in this journal}

The International Journal of Nanomedicine is an international, peerreviewed journal focusing on the application of nanotechnology in diagnostics, therapeutics, and drug delivery systems throughout the biomedical field. This journal is indexed on PubMed Central, MedLine, CAS, SciSearch ${ }^{\circledR}$, Current Contents ${ }^{\circledR} /$ Clinical Medicine,
Journal Citation Reports/Science Edition, EMBase, Scopus and the Elsevier Bibliographic databases. The manuscript management system is completely online and includes a very quick and fair peer-review system, which is all easy to use. Visit http://www.dovepress.com/ testimonials.php to read real quotes from published authors. 